\title{
Contextualizing Chaoben: On the Popular Manuscript Culture of the Late Qing and Republican Period in China
}

晚清民國時期的民間抄本

Between $185^{\circ}$ and 1950, China enjoyed a vibrant popular manuscript culture.* Books hand-copied by brush ${ }^{1}$ proliferated in the large cities, market centers, and even in many villages. At first glance, it seems paradoxical that handwritten materials would flourish at the very time that printed matter was increasingly available, often in inexpensive, illustrated lithographed editions sold in bookstores and local markets. By the 1920s, printed copies of virtually every popular and well-known text in China had been reproduced for sale and circulated widely. Yet thousands of people continued to copy these texts by hand for use in daily life, and they handwrote notebooks for their own reference. This chapter explains why the practice of hand-copying materials continued and how they were used.

I began collecting these books in 2004, and all the examples used in this chapter come from my personal collection. They are all one-of-a-kind notebooks [bijiben 筆記本], also referred to in this study as booklets, since they usually contain fewer pages than books and have the feel of an informal

* I gratefully acknowledge two scholars who assisted me in my initial forays into the world of chaoben: He Zhaohui 何朝暉 of Shandong University and Li Ren-Yuan 李仁淵 of Academia Sinica, mentioned in the Acknowledgments to this book and below in this chapter. Lin Weiping 林瑋平 of Taiwan National University made helpful comments about my research. Neighboring cultures that adopted Chinese characters for writing, specifically Japan, Korea, and Vietnam, did not have the sort of flourishing handwritten chaoben culture that China enjoyed. Certainly handwritten copies of books were made and circulated in manuscript form. They were often produced by literate people for other literate people, and they tended to have religious or literary content. For recent scholarly studies on the book culture, chiefly of printed books, in East Asia, see Joseph P. McDermott, A Social History of the Chinese Book: Books and Literati Culture in Late Imperial China (Hong Kong: Hong Kong University Press, 2006); Peter Kornicki, The Book in Japan: A Cultural History from the Beginnings to the Nineteenth Century (Honolulu: University of Hawai'i Press, 2001).

1 Note that throughout this book, the terms "handwritten," "hand-copied," "notebook," "booklet," "book," and "manuscript" are all used to refer to chaoben.

(C) RONALD SULESKI, 2018 | DOI:10.1163/9789004361034_003

This is an open access chapter distributed under the terms of the prevailing CC-BY-NC License at the time of publication. 
compilation. My best efforts to date these materials find that the majority were produced after 1850 . In general, they were for the copier's personal or professional use. At present, these booklets are widely available in China's book, antiques, and flea markets.

Some libraries and research institutes in China are collecting them, but relatively little research is being done on these materials or using them. The most active scholar in China who uses chaoben as a way to gain insight into the lives of ordinary people is Wang Zhenzhong 王振忠 of Fudan University. He is an avid collector of chaoben and old documents, and his work depicts the context in which they were used. He carefully preserves his large personal collection in good condition against the ravages of moisture and insects. He has written about how he acquires some of the materials in his collection. ${ }^{2}$

Li Ren-Yuan 李仁淵 at the Academia Sinica in Taiwan is engaged in reconstructing local society in northeastern Fujian Province. He is investigating the written materials, both printed matter and chaoben, held by people in villages in that region. They range from genealogies to books for practical use, along with items that reflect the waves of thinking that penetrated even remote areas of South China over the past several hundred years. His work plays a major role in defining and documenting the culture of South China. He is an expert at reading these materials and analyzing them from the point of view of their living past, and he explains that they were a vital part of people's lives, a point of view that was strengthened by the time he spent living in rural Fujian and investigating all the old materials the families there had purposefully preserved and were happy to show him. He lectures widely in Taiwan and China about these materials and the implications about daily life that they reveal. Ren-Yuan is one of my "teachers" who taught me how to read chaoben. ${ }^{3}$

2 Wang Zhenzhong 王振忠 explains his interest and illustrates his approaches to these materials in his Richu erzuo 日出而作 [Rise Early and Work] (Beijing: Sanlian shudian, 2010). He concentrates on Huizhou 徽州, Anhui 安徽 Province, and uses, among other materials, old documents and chaoben from Huizhou in order to sketch the life and times of society there. See idem, Huizhouyanjiu rumen 徽州研究入門 [An Introduction to Research about Huizhou] (Shanghai: Fudan daxue chubanshe, 2011). He wrote this as a research guide for students.

3 Li Ren-Yuan has been working with Michael Szonyi at Harvard, who is also interested in South China. Li is continuing the ideas he outlined in his first book, Wan-Qing de xingshi chuanbo meiti yu zhishi fengzi: Yi baokan chuban wei zhongxin de taolun 晚清的新式傳播媒體與知 識份子：以報刊出版為中心的討論 [New Media and Intellectuals during the Late Qing: On Periodicals and Publishing Institutions] (Taipei: Daw Shiang, 2005, 2013). His dissertation is Ren-Yuan Li, "Making Texts in Villages: Textual Production in Rural China during the MingQing Period" PhD, Harvard University, 2014. His dissertation advisers were Mark Elliott and Michael Szonyi. 


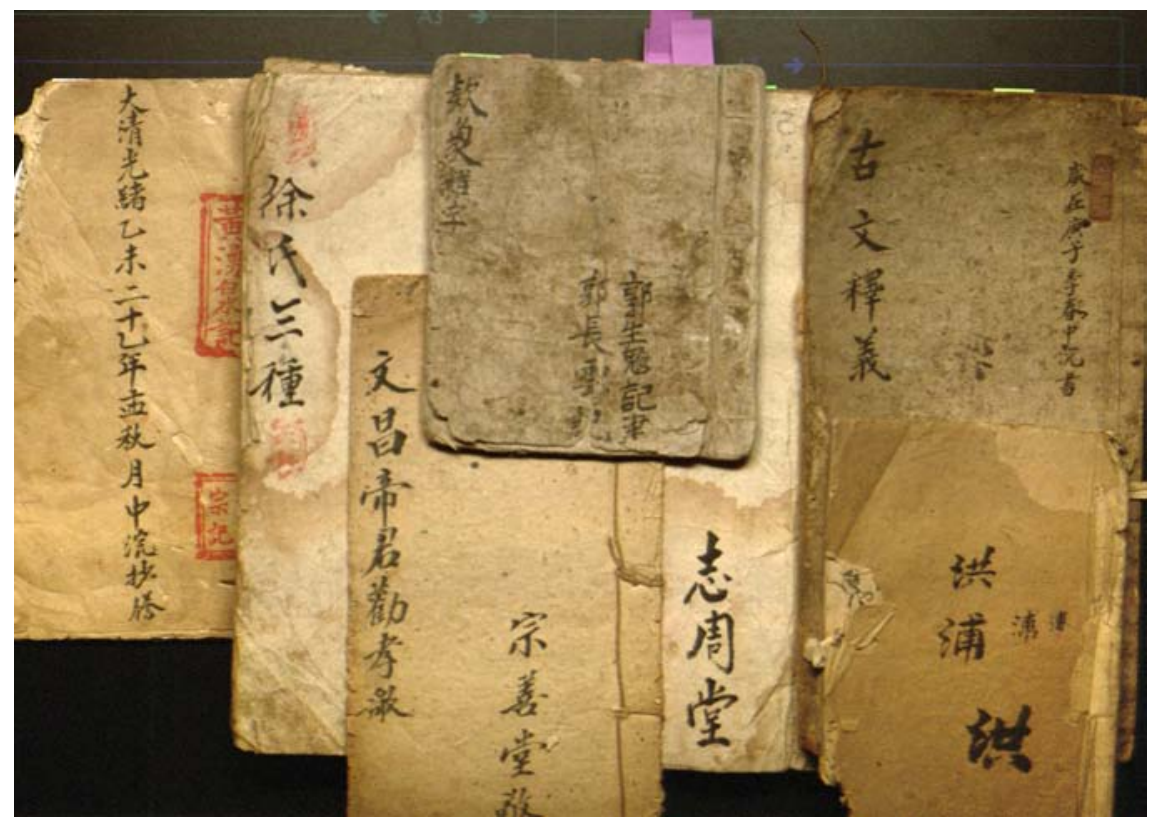

FIGURE 1.1

Chaoben Covers. Reading right to left, the covers are: Ancient Texts Explained [Guwen shiyi 古文 釋義]; Various Words Offered to the People [Kuanzhong zazi 欵眾雜字]; Song by the Wenchang Emperor Advocating Filial Piety [Wenchang dijun qinxiao ge 文昌帝君勤孝歌]; Three Items for $M r . X u$ [Xushi sanzhong 徐氏三種]; Writing Talisman [Shu fu fashi 書符法事]. All these chaoben are discussed in this book.

PHOTO BY AUTHOR

Another teacher to whom I am equally indebted for showing me how to read and understand chaoben is He Zhaohui 何朝暉 of Shandong University. We met in 2006 when he was a postdoctoral fellow at the Fairbank Center for Chinese Studies at Harvard. He specializes in the Ming 明 dynasty (1368-1644) and in philological studies and rare books, in particular, the imperial examination system during the Ming dynasty. He is also able to discuss the handmade paper used in old books and comment on their manufacture. ${ }^{4}$

Zheng Zhenman 鄭振滿 uses handwritten contracts and genealogies to reveal details of premodern local society in South China. His lively and poetic

4 Among his many publications is He Zhaohui 何朝暉, “'Mingshi, Yiwenzhi' yu Mingdai wenxian 『明史.藝文志』與明代文獻 [Record of Books in the Ming History and Ming Literature], Daitōbunkadaigaku kangakukai shi 大東文化大學漢學會誌 [Journal of Sinological Studies of Daito Bunka University], no. $5_{2}$ (March 2013). 
writing enables the reader to see the reflection of the green hills in the water of the flooded paddy fields and to feel the quiet serenity of the fertile landscape in the southern climes. ${ }^{5}$

Wang Ermin 王爾敏 is a scholar trained in Taiwan and China who works with chaoben. His teacher was the late Dai Xuanzhi 戴玄之 (1922-1990), who also wrote about history and local people, especially about secret societies, in a way that highlighted the customs and beliefs of common people trying to survive during the Republic in unforgiving times. Wang appreciates the value of the handwritten materials, including the vocabulary lists that are mentioned below, but he wants the readers to draw their own conclusions about the meaning of the old documents he discusses, so he often provides minimal interpretive comments. He reprints lengthy chaoben passages, pointing out the main themes he has observed but then leaving it to the reader to draw other meanings from the text. ${ }^{6}$

A librarian working in Tianjin, Li Guoqing 李國慶, is determined to preserve as much of China's recent literary output as possible, because many books produced for popular consumption are being haphazardly discarded. Among other interests, Li collects vocabulary lists, classifying them according to their presentation style, such as four-word lists. Li is a graduate of Peking University, where he specialized in library studies. At present, he is in charge of the Historical Documents Section of the Tianjin Library [Tianjin tushuguan, lishi wenxianbu 天津圖書館, 歷史文獻部]. He has collected and reprinted the texts of several hundred vocabulary lists produced from the Qing dynasty (1644-1911) to the present. Zazi leihan 雜字類函 [Vocabulary Lists], an elevenvolume work published in 2009, is a bibliography of works he has collected and classified. The bibliography lists 168 titles, covering eighty topic areas divided into thirteen categories. His goal is to describe each book in ways that will identify them and allow scholars to judge their potential research value. As with most handwritten works, many of the vocabulary lists discussed in this study are missing useful information such as clear dates and place names. Each entry has some identifying information on the title, often the first and last line of the

5 See, e.g., Zheng Zhenman 鄭振滿 et al., Xiangtu Zhongguo: Peitian 鄉土中國: 培田 [Rural China: Peitian] (Beijing: Sanlian shudian, 2005).

6 See, e.g., Wang Ermin 王爾敏, Ming-Qing shehui wenhua shengtai 明清社會文化生態 [The Cultural Environment of Ming and Qing Society] (Guilin: Guangxi shifandaxue chubanshe, 2009); see also Dai Xuanzhi 戴玄之, Hongqianghui 紅槍會 [The Red Spears] (Taipei: Shihuo chubanshe, 1973), published in English as Tai Hsüan-chih (Dai Xuanzhi), The Red Spears, 19161949, trans. Ronald Suleski (Ann Arbor: Center for Chinese Studies, 1985). 
collection, with other names or identifying information as to its origin when they appear in the collection. ${ }^{7}$

These scholars are doing pioneering work in Chinese on the usefulness of chaoben for gaining insight into the lives of people in pre-1950s China. Pioneering work in English, which links handwritten materials to local village life in South China near Hong Kong, was done by James Hayes, a former civil servant in Hong Kong and now retired scholar, who began publishing in the 196os and continues to do so today. Also noteworthy is the work of Patrick H. Hase, who writes about village practices in South China, near Hong Kong. ${ }^{8}$ These booklets were part of the popular manuscript culture [minjian chaobenwenhua 民間抄本文化] of the late Qing and early Republic. Although the idea of hand-writing texts derived from the traditional practice of students and scholars copying extensive texts in their entirety (today we sometimes refer to the best of these copies as "excellent reliable copies" [shanben 善本]), the texts produced as part of the popular manuscript culture were in a different category. First, they were not lengthy historical, philosophical, or literary texts of interest to the highly educated or the well-to-do. Second, these popular copybooks were not intended to be placed on a library shelf for circulation among scholars for the purposes of research or discussion. Third, minjian chaoben texts were not always copied in order to preserve respected writing because they often contained only portions of other texts, except for religious texts, which were copied in their entirety, especially as part of an act of devotion. ${ }^{9}$

7 Li Guoqing has written about other materials of historical interest held at the Tianjin Library but not, as of this writing (2017) on the subject of vocabulary lists. At present, he is working on a manuscript titled "Zazi leihan xubian 雜字類函續編 [Vocabulary Lists, Continued].” On his printed collection, see Li Guoqing 李國慶, Zazi leihan 雜字類函 [Vocabulary Lists] (Beijing: Xuefan chubanshe, 2009).

8 In the hope of alerting librarians in China to the usefulness of these materials for research, I wrote "Wan-Qing Minguo shiqide minjian chaoben 晚清民國時期的民間抄本 [Popular Copied Books in the Late Qing and Republic]," Shandong tushuguanxue qikan 山東圖書館 學刊 [Library Journal of Shandong], 2, no. 124 (2011): 89-93, 115. Hase's most recent book is Patrick H. Hase, Custom, Land and Livelihood in Rural South China: The Traditional Land Law of Hong Kong's New Territories, 1750-1950 (Hong Kong: Hong Kong University Press, 2013).

9 The literary and philosophical texts copied by literati, as mentioned above, were in a different category than the popular manuscripts being considered here. For details on how to judge the fine-quality hand-copied shanben works, see Shen Jin 沈津, "Chaoben jiqi jiazhi yu jianding 抄本及其價值與鑑定 [The Value and Authenticity of Copied Manuscripts],” in Shuyun youyou yimaixiang: Shen Jin shumu wenxian lunji 書韻悠悠一脉香: 沈津書目文 獻論集 [The Beauty of Books Is an Everlasting Fragrance: The Collected Bibliography and Documentary Writings of Shen Jin] (Guilin: Guangxi shifan daxue chubanshe, 2006). Ming- 
Like the shanben texts produced by students and scholars, the minjian chaoben were written on sheets of paper that were folded in the middle to form the outer edge of each page - the open edges were bound together-and a title page and back cover were added. This produced the appearance of a typical string-bound book [xiandingben 線定本] that was bound along the right margin and that opened from left to right. But the differences with scholarly handwritten texts were noticeable, especially because the minjian chaoben were often bound with inexpensive string or even with paper twisted to make twine (called maozhuang 毛裝, to indicate that the binding was temporary). It could mean that the author or compiler was planning to add more pages later. However, for some people, it was simpler and less expensive to prepare twine from scraps of paper, rather than string or thread that was needed to repair clothing. In this study, I assume that twine was used to bind pages to avoid the need to purchase string or thread. This seems a reasonable conclusion when the manuscript in question is made of very rough and inexpensive paper, likely obtained from a local market.

Inexpensive handmade paper was produced from many different plant products. Rough paper for wrapping could be made from rice straw (called "straw paper" [caozhi 草紙]). It could be used for writing as long as the paper took the writing ink without blurring and occasionally comprised chaoben. Paper made from rice straw may have been the simplest to produce, but, of course, rice was also a food staple and most people grew rice for food, not for the rice straw. Probably paper made from bamboo was more common than paper made from rice.

Paper was also made from the bark of the paper-mulberry [chu 楮], a large shrub. Such paper was highly prized during the Qing dynasty, throughout the Republican era, and down to the present day. Paper made from mulberry bark

dynasty elite manuscripts are examined in Inoue Susumu 井上進, “Zōsho to dokusho 藏 書と讀書 [Collected Books and Readers]," Tōhō gakuhō 東方學報 3 (1990); idem, "Shuppan bunka to gakujutsu 出版文化と學術 [Publication History and Academic Scholarship],” Meishin jidaishi no kihon mondai 明清時代史の基本問題 (Basic Issues in Ming and Qing History) (Tokyo: Kyūko shoten, 1997). Both Cynthia Brokaw and Joseph McDermott discuss the elite tradition, while being fully aware of the popular manuscript tradition, in Cynthia Brokaw and Kai-wing Chow, ed., Printing and Book Culture in Late Imperial China (Berkeley: University of California Press, 2005). At this point in scholarship, the study of these popular manuscripts is subsumed under the study of books and printing history. The state of the field concerning printed books is summarized in Tobie Meyer-Fong, "The Printed World: Books, Publishing Culture, and Society in Late Imperial China," Journal of Asian Studies 66, no. 3 (August 2007). 
was very durable: It deteriorated slowly and was widely assumed to be able to last a thousand years. Before the Song dynasty (96o-128o), paper made from mulberry bark was very common, and paper later made for use in the imperial palace was in general from the white mulberry. (This refers to its general designation, not to its color, which was the color of typical tree bark.) Paper makers in Korea and Japan have continued prefer paper using mulberry bark.

After the Southern Song period (1127-1279) and down to the present, the most common handmade paper in China was that made from bamboo. The material needed was easily available in many parts of China, and the resulting paper was pliant and took ink well. Bamboo paper was believed to have less longevity than bark paper and was expected to last only five hundred years. It was not uncommon for paper makers to throw other materials into the "soup" that became the viscous liquid to be strained off to form the paper. Straw fibers were longer than most other fibers in the liquid mix and could be seen when the paper was held up to light. Bark fibers were also among the longer fibers. In some papers, bundles of fiber can be seen embedded in the paper, especially in cases when the liquid mix (the pulp) was not heated (uncooked) before being strained.10

In all cases, the bark or fibers were stripped off the plants, softened by steaming and washing with water, and then pounded into a pulp. At that point, the various fibers from other suitable plants could be mixed in to strengthen the pulp. For example, some bamboo or rice stalks could be mixed in with the mulberry or bamboo. Accepted recipes called for a ratio of 6 o percent mulberry to 40 percent tender bamboo or 70 percent mulberry bark to 30 percent rice stalks. Before the pulp was ready to be made into paper, an agent to bind the fibers together was added, in some cases starch made from soybeans [huang dou 黃豆]. As the pulp was being prepared, locally available chemicals such as potash or soda ash to form lye, or chlorine bleach, might be poured in and then washed out to achieve the desired consistency and color.

A vat filled with water was prepared, and a lump of the claylike pulp was added and vigorously stirred in. Then, a large square screen in a wooden frame, often made from strips of rounded bamboo tied together with wire, silk string, or even long hair from an animal tail, was sunk into the vat below the surface of the milky water. The screen was slowly lifted up horizontally by hand with the

10 In 2016 I benefited greatly from information and advice given to me by Lü Shuxian 呂淑 賢, a rare book librarian at the Peking University Library, who spent a year as a visiting specialist at the Harvard-Yenching Library. We discussed Chinese handmade papers, and she examined a number of the chaoben from my collection that are cited in this book. 
result that a thin layer of the liquid scum remained on the top of the screen. The screen was slightly tilted to allow excess water to drain off. Some also drained off through the bamboo screen and into the vat. At this point, some impurities, such as small fibers, often remained in the mixture on the screen. When we look at the paper typically used by the common people for the chaoben, these impurities are visible, but as long as they were completely flat and imbedded in the paper, they did not affect the surface or the paper's ability to take ink without distortion. Moreover, when a sheet of the chaoben paper is held up to the light, the impression of the bamboo screen is also visible in the paper, like a watermark. The more impurities that are seen in the paper, the greater the chances that it was produced hurriedly and perhaps inexpertly. The lower quality of the paper reduced the price, and therefore it was more commonly used by people at the bottom of the economic ladder.

The wet sheets of "paper" could be slid (couched) off the screen and stacked as new sheets came off the screen. When a pile of perhaps ten sheets was stacked, the sheets would be pressed down slowly to allow the remaining water to be squeezed out. Then, after a sheet was fairly dry, it would be placed on a wall or under the sun to dry completely. The entire paper-making process consumed many days and weeks, because it comprised repeated washing and steaming to strip down the plant fibers, to form the pulp, and then to dry each sheet. Preparing the pulp was the most time-consuming part, but after the vat and its liquid were ready, many sheets could be produced from a single vat in a short period. Many of these chaoben used paper that had not been bleached, and the chaoben I have found have aged to a naturally occurring shade of brown or tan. ${ }^{11}$ The handmade paper used in Qing- and Republican-era chaoben is almost always very pliant. The best of it is like thin cloth, some of which will not tear but, instead, will pull apart like disintegrating cloth.

11 For a description of making paper for manuscript and printing use, see Jacob Eyferth, Eating Rice from Bamboo Shoots: The Social History of a Community of Handicraft Papermakers in Rural Sichuan, 1920-2000 (Cambridge: Harvard University Asia Center, 2009). The basic process of handmade paper production is described on pp. 25-30. See also Joseph Needham, ed., Science and Civilization in China (Cambridge: Cambridge University Press, 1985); vol. 5, pt. 1, by Tsien Tsuen-Hsuin (Qian Cunxun) 錢存訓, is on paper and printing; the

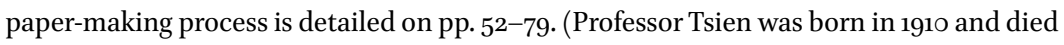
in Chicago in April 2015 at the age of 105, as this chapter was being written.) Informative comments are made about handmade paper in China in Lucille Chia, Printing for Profit: The Commercial Publishers of Jianyang, Fujian (nth-17th Centuries) (Cambridge: Harvard University Asia Center for the Harvard-Yenching Institute, 2002), 327-330 nn. 3-25. 
The quality of the paper used for the handwritten texts in the market indicates that they were prepared for the common people from inexpensive materials locally available. ${ }^{12}$ The quality of the calligraphy in those texts allows us to judge the educational level and formal training of the person who wrote them. The calligraphy varies from that of a novice to that of someone relatively well trained. Most minjian chaoben were written using "regular script" [kaishu 楷 書], though nonstandard characters (called "popular characters” [suzi 俗字]) and incorrect characters, which were homophones of the correct ones, are frequently encountered. Judging people's level of formal education by the quality of their calligraphy is an inexact science, because not all traditionally educated scholars took pains to write beautiful characters. Nevertheless, in general, writing artful characters with a brush was considered a standard part of the educational curriculum, so it seems a reasonable indication of the formal educational level attained by the person who copied a text.

\section{Popular Chaoben in Chinese Society}

When I first began buying these chaoben, because they attracted and intrigued me, I had only a vague idea of what they were, and I was confused about their place in Chinese society. I was told most of them had been discarded by the families that possessed them. What value, then, should I give them? I did not want to engage in theory building about what I was buying, but I wanted to place them in a meaningful context. I came to believe that the minjian chaoben, unlike the texts with some academic value copied by scholars, concern the interests, concerns, and aspirations of the great mass of ordinary Chinese. These booklets should be seen as cultural artifacts created by Chinese people during the crucial century from 185 o to $1950 .{ }^{13}$

12 So far, I have not found any chaoben on paper-making, but I obtained a related handwritten manuscript that is a two-volume string-bound set on the intricacies of cutting woodblocks, by Liu Fengge 劉鳳閣 [Liu Phoenix Hall, which could also be the name of the author of this text]. It appears to have been written in late 1936 with notes and the date January 1937 added. The earlier date—Kangde 康德 3 (1936)—refers to the Manchukuo 滿洲國 period. Volume 1 is thirty-two pages, volume 2 is forty-six pages, each is 8 in $(20.32 \mathrm{~cm}) \mathrm{h} \times 5^{1 / 4}$ in $(13.34 \mathrm{~cm}) \mathrm{w}$, purchased in Harbin, January 2013.

13 One of the more recent chaoben I have obtained is a Xue Family Genealogy dated 1982: Xueshi jiapu: Shiliu shisun Xue Zhonghe jinchao bingbu 薛氏家譜：十六世孫薛中和謹 抄并補 [Xue Family Genealogy: Carefully Copied with Additions by Sixteenth-Generation Xue Zhonghe]. This copy uses bleached machine-made paper of good quality. Mr. Xue, who 
I define these works as cultural artifacts based on my understanding of the dynamics of cultural creation, using the explanation endorsed by the eminent Harvard medical anthropologist Arthur Kleinman. He wrote that culture is a process that emerges out of the patterns of everyday social life. In this view, culture is a product created by average people. It is not abstract and distant; it is concrete and relevant. The culture that most people create emerges from common sense taken for granted. Even if the elements of this culture are based on a grand philosophical or religious worldview, the particular culture being created by most people must exhibit a logic that is understandable and meaningful to the average person. ${ }^{14}$ The majority of chaoben that I have collected fall into this category.

Culture is historically determined because it draws on the influences, values, and symbols that have affected the people creating the culture. But the "distant" historically determined elements are transformed by the common people in ways that can meaningfully influence their everyday lives. People always engage in this reinterpretation because the culture that an individual embraces needs to be intimate and deeply relevant to them. Cultural symbols or values that are too distant (in historical time) or too abstract (in conceptual terms) can lose their meaning for ordinary people in everyday life.

The personal culture of each individual merges with the values and perceptions of the people around them to form the dominant culture among their peers. The immediate dominant culture consists of the ways of being and doing, the preferred forms of ordinary interpersonal interaction, and the socially elaborated bodily states understandable to the ordinary people who are creating and living the culture. These elements, in turn, converge to recreate social life in its local specificity. In other words, the culture created by ordinary people is always relevant to their specific time and place and to the local

was sixty-eight years old when he made this copy, used complex, or traditional, characters throughout although simplified characters have been officially taught and used in China since the 1960 . It is 11 in. $(27.94 \mathrm{~cm}) \mathrm{h} \times 6 \frac{1}{2} \mathrm{in}$. $(16.51 \mathrm{~cm}) \mathrm{w}$ and comprises 19 folio (folded) pages, purchased in Shanghai in January 2013.

14 Kleinman endorsed this view of culture in Roberto Lewis-Fernandez and Arthur Kleinman, "Cultural Psychiatry: Theoretical, Clinical, and Research Issues," Cultural Psychiatry, 18, no. 3 (September 1995): 434; see also Arthur Kleinman, "How Is Culture Important for DSM-IV?" in Culture and Psychiatric Diagnosis; A DSM-IV Perspective, ed. Juan Mezzich et al. (Washington, DC: American Psychiatric Press, 1996). This broad and relaxed explanation of culture is suitable to these materials because it takes them on their own terms. 
circumstances in which they live. We need to accept variants in cultural patterns and expressions as to-be-expected manifestations of the real cultures of living people. ${ }^{15}$

This broad and relaxed definition of culture is appropriate here for several reasons. First, it shows that culture is never fixed. Instead, it evolves over time through people's interactions with the historical, social, and political contexts that they experience, which are perpetually in flux. Second, it explains culture as a product of people. Although everyday lives are regularly influenced by culture transmitted through institutions or received as part of a general milieu, living people create and transmit culture. In this view, culture is not a top-down phenomenon that engulfs a passive people; rather, culture is just as much a bottom-up process created by people in the course of their lives. The culture that these people create is always modified and practiced in ways that fit their lives.

Moreover, this definition tells us that we need to appreciate culture within its local setting. At the local level, we assume we will find variations in cultures because they are practiced and created by people in ways that make sense to them. Local variations of a cultural phenomenon do not disrupt or deny the greater orthodox practices of a major cultural tradition, but the local variations are modifications to be expected in the pattern of more widely followed practices. An examination of any cultural practice in a specific location invariably reveals modifications preferred by the local people. ${ }^{16}$

The chaoben that I have collected are all cultural artifacts, produced by ordinary people. The people who copied these texts were cultural creators dealing with the grand value statements and symbolic representations of historical

15 Chinese have joked and made fun of their high culture, at the same time that they were subject to its values. Another example of this in East Asia is Korean village folk dances that make fun of the yangban 両辦 elite. In China, temple fairs sometimes became events for clowning and revelry, discussed in Zhao Shiyu 趙世瑜, “Zhongguo chuantong miaohui zhong de kuanghuan jingshen 中國傳統廟會中的狂歡精神 [The Spirit of Revelry in Traditional Chinese Temple Fairs]," Zhongguo shehui kexue 中國社會科學 [Chinese Social Science], 1 (1995).

16 In this regard, the fieldwork of Daniel Overmyer gives many examples of how people in North China conduct local village religious ceremonies based on their own interpretations of their relationships with the gods and spirits of their communities. See Daniel L. Overmyer, Local Religion in North China in the Twentieth Century: The Structure and Organization of Community Rituals and Beliefs (Leiden: Brill, 2009), published in Chinese as Fan Lizhu 范麗珠 and Ou Danian 歐大年 (Overmyer), Zhongguo beifang nongcun shehui de minjian xinyang 中國北方農村社會的民間信仰 [Popular Beliefs in North China Villages] (Shanghai: Shanghai renmin chubanshe, 2013). 
China, but they altered those grand elements from their distant culture to produce a locally specific cultural item that was relevant to their daily lives.

Such texts were needed for practical purposes, often to help people deal with matters such as marriage, disagreements, or the need for more knowledge. Each of these booklets had a value in the economic exchange of goods and services. For example, the fortunetelling texts were used by fortunetellers [suanmingshi 算命師] to earn income. Some texts were used by teachers who earned a living by giving students elementary education. The religious texts were used to reinforce community bonds among people who were likely to contribute goods or money to help sustain their local ritual specialist.

Each of these texts was used in daily intercourse among people. They were laid on the altar of a local temple to be consulted by priests and laypeople. They were carried in the packs of itinerant fortunetellers or by yinyang masters [yinyangshi 陰陽師] as they moved from one location to another seeking business. They were set out on the table of the legal advisor as he discussed a family matter with a concerned client, possibly at a table at a periodic market.

The fact that these were working texts, intended for use in the course of daily life, can be illustrated in several ways. The strongest indicator is that many of them contain a variety of materials. It is common to find two or more distinct texts on different, sometimes seemingly unrelated topics on a page. This is because the books reflect the personal interests and needs of the user who copied the texts or who paid to have them copied, not for some unknown general reader. In addition, many of the people who owned these books used them as notebooks in which to jot down other unrelated information that was useful or interesting to them. We can find instances in which someone wrote down a recipe for traditional Chinese medicine or kept an account of recent purchases, a teacher who listed the names of some of his students, or a copyist who added an interesting story at the end of the text-examples discussed below. Although they are bound as books, usually with a title on the cover, it is useful conceptually to think of them as personal notebooks in which the copyist or the owner wrote down information of personal importance.

One often finds that these booklets show a lot of wear and tear and that the paper has become very thin, stained, or discolored, especially where it was frequently handled. The most recent of these manuscripts is now at least fifty years old, and most are more than a hundred years old, so some discoloration is to be expected. These manuscripts were in frequent use because they were intimately connected to their daily lives. The discoloration indicates what a personal and perhaps even indispensable item they were for the common people. They needed the information in these manuscripts for both ordinary quotidian 
activities and important life events, whether marriage, filing a lawsuit, or learning to gain enough literacy to get a job.

China's popular manuscript culture remained a living tradition throughout the first half of the twentieth century. The handwritten texts in my collection exemplify this tradition, which remained vibrant among the common people for so long because the materials being copied were needed for a practical and more or less immediate purpose. They were notebooks in which useful information was kept for reference. Their value lay with the person who copied the materials for his own use, but in most cases they had limited value on the open market because their contents were usually so specific to that person and because they often contain miscellaneous notes. Most writers did not seem to have any intention of having such manuscripts available on the market because they often added personal details to the pages. However, they rarely wrote their own name, address, or any other identifying information because the text was for their own use and not intended to be read by members of the public.

It is precisely the eclectic mixture of texts and miscellaneous information that makes these hand-copied books so interesting as cultural artifacts. They are a marker for the specific time and place of the person who copied themoften someone who otherwise might not have left behind particular written materials because he did not have a connection to elite education and the written word and did not engage in its creation for scholarly or intellectual purposes. Some of the texts I've collected show the hand of a person with little formal training in the use of the brush. Those written characters are heavy and far from elegant. Many of the texts in my collection show the hand of a person with obviously some degree of formal education and training in calligraphy, a person comfortable and competent in writing with the brush. But his brush was being put to use to assist a person of lesser social or educational standing, and to assist himself in earning income, as discussed in Chapter 7 , whose writing is contrasted with that of his better-placed compatriot in South China.

A common assumption made here is that many of the people in this period who worked with written materials, specifically with those in my collection, were lower-degree holders such as xiucai. These men had received several years of basic education, including China's history, literature, and philosophical traditions. They had spent years practicing writing with a brush, so their calligraphy could be adequate. After a number of years of study, which began when they were seven or eight years old, they would at the age of sixteen or seventeen take the county-level government examinations to obtain a xiucai degree. Some students failed the examination or, often for financial reasons, suspended their formal study before taking it. All these men were able to read and write and were knowledgeable about China's cultural past but needed to make a 


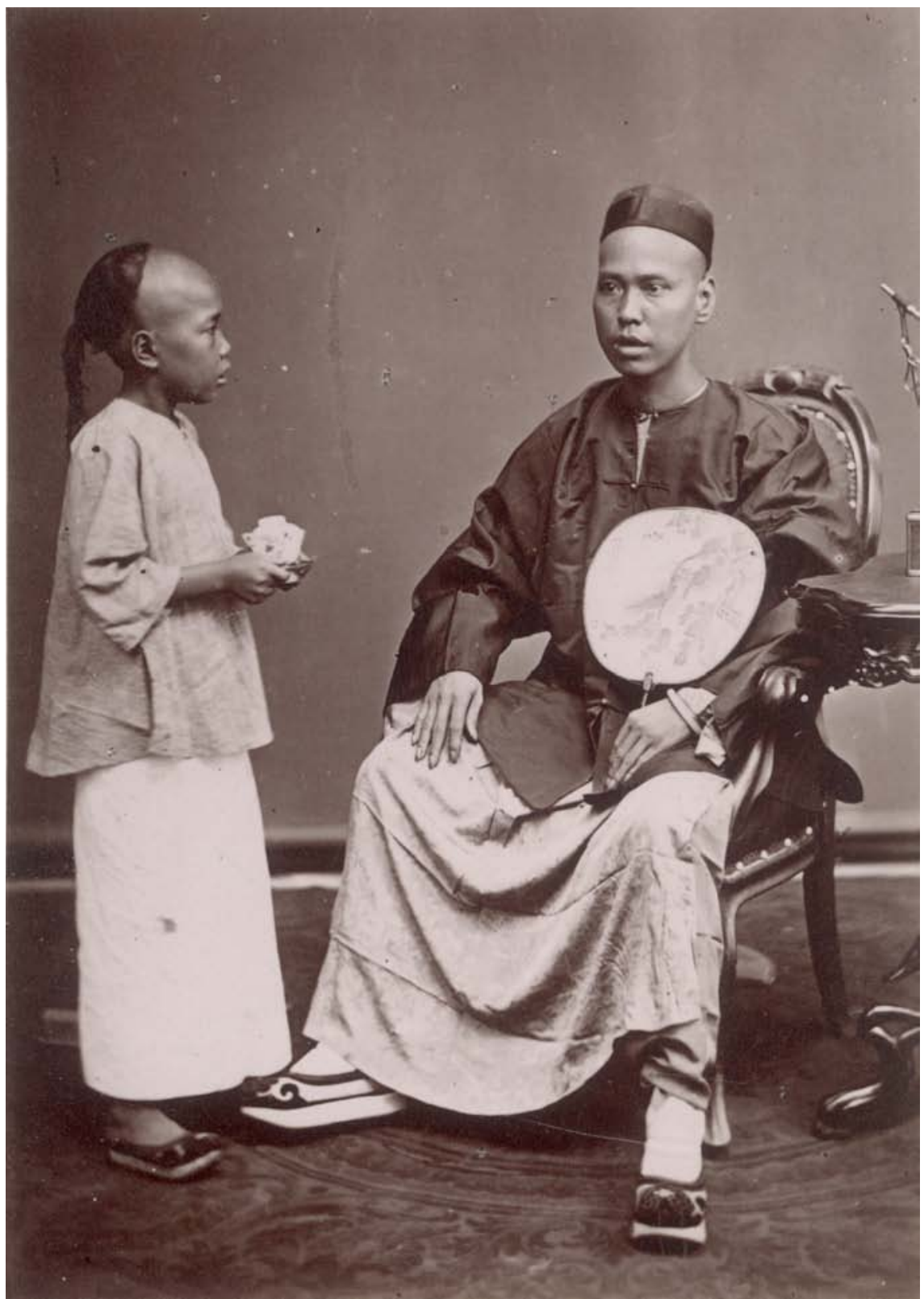

FIGURE 1.2

Xiucai Scholar 秀才. The young xiucai scholar proudly wore his robes and cap as a mark of his status. Chinese man and boy in Singapore. Date circa 1890, English: Photograph-Albumen print gold toned. 
living. They often took up professions, as mentioned in the Introduction, as a village school teacher, fortuneteller, legal advisor, herbal doctor, or scribe [daishu 代書] who wrote letters and documents for others. Others were government clerks or small businessmen who had a basic education and regularly used a brush in the course of their work, meaning that their writing was clear, yet their social status was not considered high. Some scholars have suggested that local merchants were strong consumers of handwritten and printed texts because they were attempting to raise their social position through the acquisition of these symbols of culture and education. ${ }^{17}$

\section{Striving for Basic Literacy}

The ability to read, and possibly also to write, divided Chinese society between those permanently relegated to the lower strata of society and those who could, at least in theory and not infrequently in practice, raise their social and economic status. For many people in China, being able to read and write not only opened the door to intellectual pursuits but, more important, created the possibility of gaining a more lucrative source of income. For those at the bottom of the social and educational ladder, for whom even a year or two of schooling was beyond their means, glossaries called "vocabulary lists" [zazi 雜字] were the basic tool most in demand.

A young person who obtained a copy of a vocabulary list could largely teach himself how to recognize and write some characters. Someone older needed

17 Xiucai 秀才 is used here as a proxy for literate people who turned to various types of work to earn a living. They could equally be assumed to have been clerks or scribes. As emphasized above, it is likely that the people engaged in the professions discussed here were all literate persons with some degree of formal education whose careers did not progress to completion of a higher degree or appointment to a government office. In that sense, the men in these professions were students at various, though mostly the lower, rungs of the educational ladder. They might have been licentiates, sometimes also referred to as xiucai, imperial academy students [jiansheng 監生], or holders of a purchased degree [gongsheng 貢生], which can be translated as "tribute student." See Evelyn Sakakida Rawski, Education and Popular Literacy in Ch'ing China (Ann Arbor: University of Michigan Press, 1979); see also http://wn.wikipedia.org/wiki/Imperial_examination/, accessed June 23, 2009. Useful comments outlining the traditional education system are in H.S. Brunnert and V.V. Hagelstrom, Present-Day Political Organization of China (1911, repr. Taipei: Book World Company, n.d.). The position of these low-level scholars is discussed in Benjamin A. Elman, Civil Examinations and Meritocracy in Late Imperial China (Cambridge, MA: Harvard University Press, 2013). 


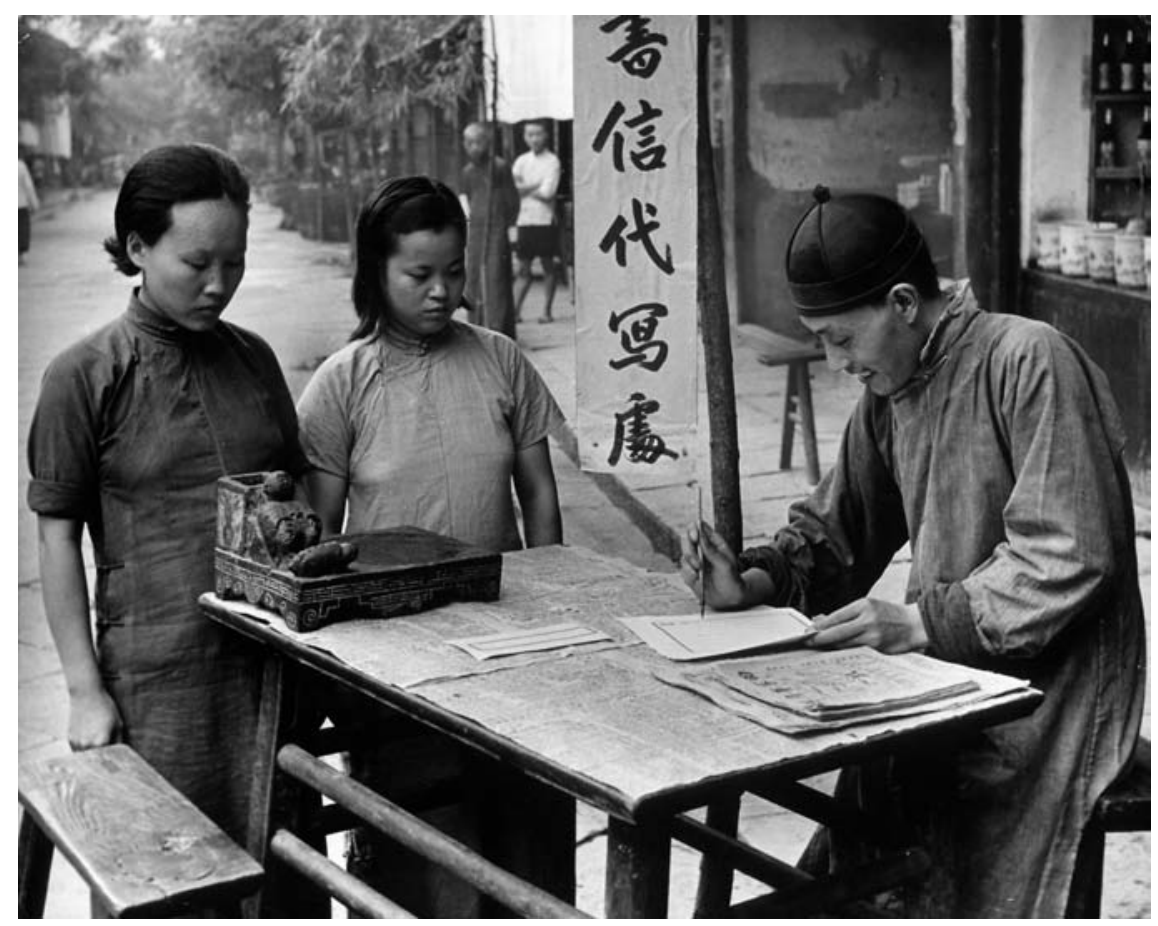

FIGURE 1.3

Scribe. This photo shows a scribe [daishu 代書] writing on behalf of people who were unable to read or write well. The photo was taken in 1941 in Chengdu 成都, Longquanyi 龍泉驛, Sichuan 四川 Province (present-day Longquanzhen 龍泉鎮?), by Carl Mydans, a photographer for Life Magazine, who traveled to various war-torn regions and was photographing in China at the time. PHOTO BY CARL MYDANS, THE LIFE PICTURE COLLECTION, GETTY IMAGES

only to read aloud the words for that student to understand the meaning of the written characters that comprised them. If the words were arranged in short rhymes, the student could identify the characters he needed to learn more easily by memorizing the rhymes. Copying the character again and again provided entry-level exposure to the written word, without the need to pay a teacher or take the time to attend classes. Most vocabulary lists were written in pocket-sized editions, which the young apprentice or store clerk could easily carry with him all day. 18

18 The role of the $z a z i$ as a basic tool for education and inculcating social and moral values is discussed in Wang Youying 王有英 “Minjian shizikeben zhong de jiaohua yiyi 'zazi' yu shehui jiaohua 民間識字課本中的教化意義雜字與社會教化 [The Socialization Function of Vocabulary Lists as Textbooks for Popular Education]," Xinan shifan daxue 
The contents of most vocabulary lists were specific to their time and place. The words introduced help us to distinguish between a Qing and a Republican text. For example, the words used to describe items of clothing or government offices, changed between the two periods. The words referring to agricultural crops, to grains and fruits, also differed between the northern and southern parts of the country, so we can ascertain the general geographic location where the text was written. Many vocabulary lists contain words in local dialect for tools, items of clothing, or foods. Some native speakers of Chinese can point out such regional usage, which help to pinpoint the geographic origin of a text. ${ }^{19}$

Vocabulary lists were extremely popular in China at the end of the Qing dynasty, judging from the large number of them available for purchase today. One of the vocabulary lists in my collection is titled A List of Characters to Teach the People [Shenqun shunzi 申群順字]. This publication presents loosely rhyming four-word verses [siyan zazi 四言雜字]. It is not divided into sections or categories; the verses simply run from the beginning to the end of the text. It contains 500 characters, most of which are words for items that might commonly be found in a general store or market.

The heavy hand of the copyist tells us it was probably the student himself who copied this book. He had received some training in calligraphy, it appears, but was still at an early stage of practice. From the items mentioned on this first page, we can guess the text was made in North or Northeast China, where these would all be typical food items. The rather poor quality of the paper, which would be for wrapping bundles, might also indicate a rural part of North China. The title page says, "Written on June 12, 1930 [in the intercalary month of June], in the summer" [Minguo shijiunian runliuyue shi'errixia li 民國拾㺵 年閏六月十二日夏立]. An inspirational phrase is penned in the student's poor calligraphy: "The mountains are high and the rivers long" [Shan'gao shuichang 山高水長; p. 1]. The implication of the phrase is that students need to broaden their horizons.

xuebao 西南師範大學學報 [Journal of Southwest Normal University], 31, no. 2 (2005). A brief overview of the chronological development of vocabulary lists in Chinese history is given in Gu Yueqin 顧月琴 and Zhang Hongfeng 張紅峰, “Zazi (Zhongguo minjian shizi jiaocai) zai Riben de liuchuan ji yingxiang 雜字 (中國民間識字教材) 在日本的流傳及 影響 [Vocabulary Lists (Popular Chinese Educational Texts); Their Spread and Influence in Japan]," Guojia jiaoyu xingzheng xueyuan xuebao 國家教育行政學院學報 [Journal of National Academy of Education Administration] 7 (2008).

19 Rawski discusses a Shandong dialect vocabulary list, in her Education and Popular Literacy in Ch'ing China. 


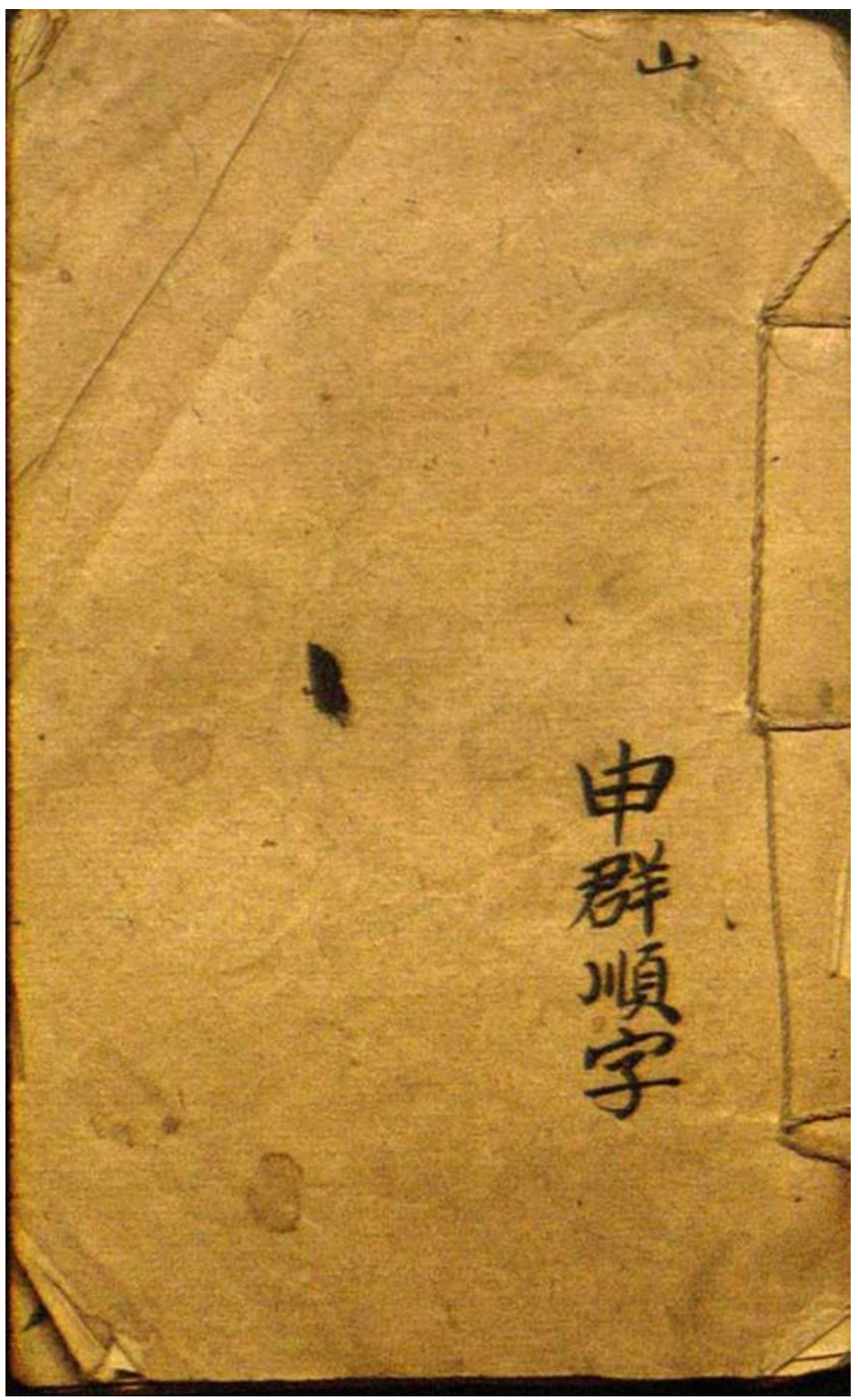

FIGURE 1.4

A List of Characters to Teach the People [Shenqun shunzi 申群順字], Cover. This vocabulary list [zazi 雜字] can be considered a classic example of the genre: It introduces a series of words; it is written in simple four-word rhyming phrases; the calligraphy indicates this was copied by a student who had only a limited formal education. The first three characters, Shen Qunshun 申群順, could also be read as the name of a person, but in this book I have read it as shenqun 申群 “Teach the People."

PHOTO BY AUTHOR 


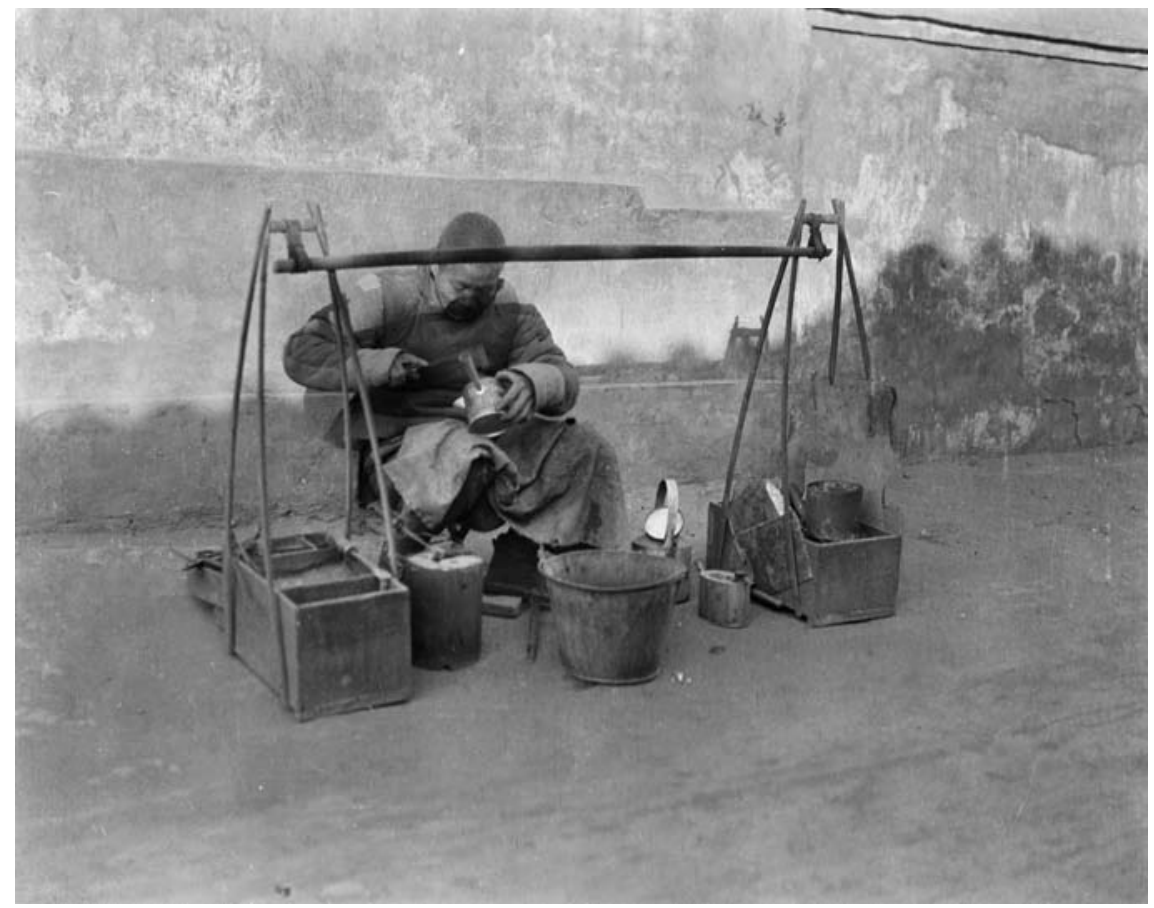

FIGURE 1.5

A Tinsmith. This member of the pingmin worked with light metals to repair pots, cooking pans, and vessels that carried liquid. He probably did not have his own shop and perhaps could not afford to maintain one, but instead wandered through the streets and alleys [hutong 胡同] calling out his services. Photo taken about 1918 in North China.

SIDNEY D. GAMBLE PHOTOGRAPHS, DAVID M. RUBENSTEIN RARE BOOK \& MANUSCRIPT LIBRARY, DUKE LIBRARY

Following the lists of everyday vocabulary, this collection ends with words that give moral instruction. Many vocabulary lists were only a series of common words, usually in rhyming couplets as an aid to memorization. Some vocabulary lists expanded on the lists of words in order to introduce an element of moral instruction. Not all vocabulary lists included moral or other advice, though the Chinese of the Republican period seem to have taken every opportunity to offer comments on personal morality, virtues, and the proper role of individuals in society.

The emphasis in this volume is on following accepted social norms and the blessings that derived from doing so. The phrases include: "Respect heaven and bow to the earth" [jingtian lidi 敬天禮地]; “honor the ancestors and make offerings to the gods" [jizu jizong 祭祖祀宗]; “obey your parents" [xiaoshun fumu 孝順父母]; "may your children and grandchildren increase" [ fada zisun 


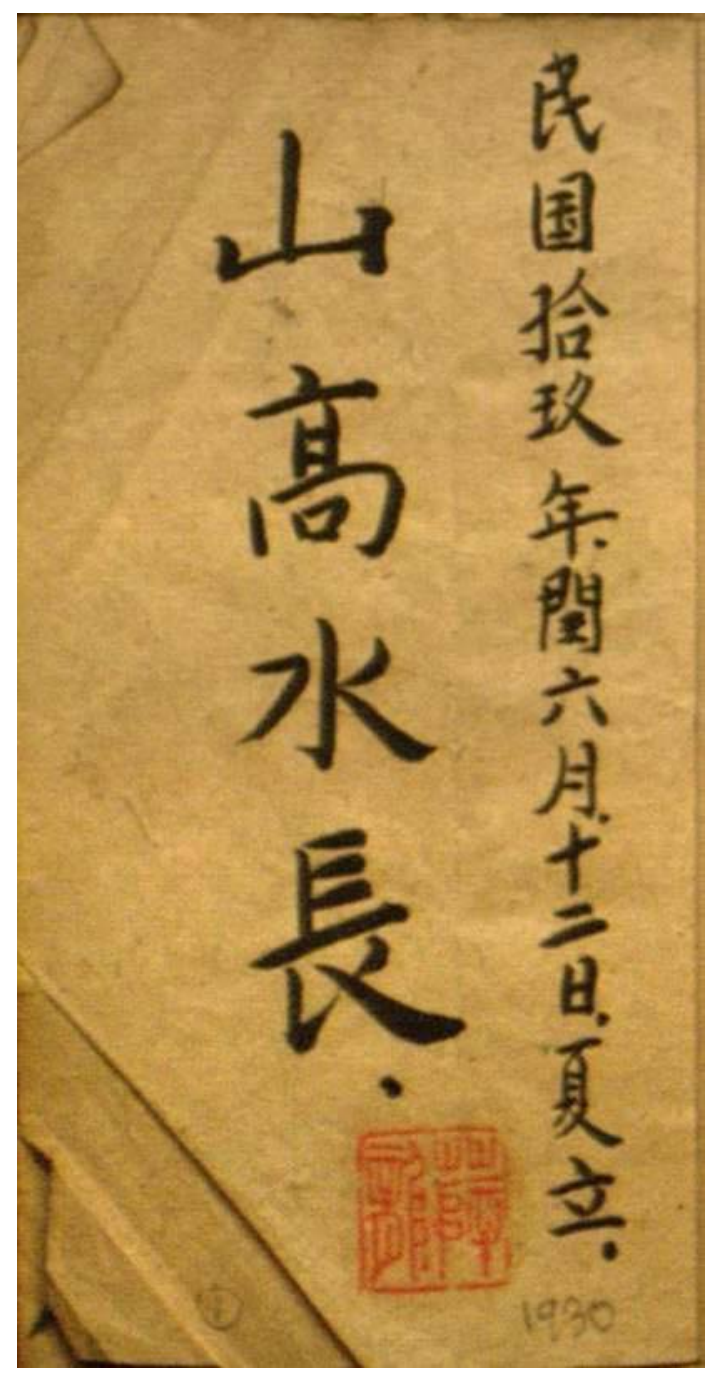

FIGURE 1.6

A List of Characters to Teach the People [Shenqun shunzi 申群順字], Page 1, The Motto. The motto, written in 1930, reads "The Mountains Are High and the Rivers Long” [Shangao shuichang Ш 高水長], with the implication that students need to broaden their horizons. The seal at the bottom of this page is mine, showing that the book belongs in my collection.

Pното BY AUTHOR 
發達子孫]; “may your good fortune be as [great] as the eastern sea" [furu donghai 福如東海]; “may your blessings increase” [luwei gaosheng 祿位高陸]; "may your life be as long as the southern mountains" [shou bi nanshan 壽比 南山]; “may your home overflow with good fortune" [xiqi yingmen 喜氣盈門]; "pearls [of fortune] will line the riverbank" [zhuhuan hepu 珠還合浦]; “may you enjoy overwhelming good luck" [ yunzhuan hongjun 運轉鴻鈞] (see pp. 22-23). These maxims assert the benefits that will accrue from following the teachings set out in the text. Other phrases are often used in standard New Year's couplets [duilian 對聯]. This chaoben is also discussed in Chapter 3 .

\section{A Note on Vocabulary Lists}

Up to this point, I have emphasized the role of vocabulary lists as a self-learning tool. As mentioned earlier, the vocabulary lists contain terms with relevance to daily life. In that sense, they are invaluable compendia of items, paraphernalia, and personal accoutrements that enable us to reconstruct people's daily lives at a particular time. Some vocabulary lists are illustrated, which facilitates linking the written word to the item it represents.

Then and now, vocabulary lists played another equally important role. They offered commentaries on the social setting in which people found themselves and regularly strove to uphold conventional morality. More than that, vocabulary lists described the social and economic difficulties for those struggling to survive. They noted haughty officials, made reference to village rowdies who were both bothersome and dangerous, relatives who might pressure a family member, and the need for respecting social conventions regardless of one's personal inclinations. These and other social, cultural, and philosophical observations are made in the vocabulary lists.

Clearly the vocabulary lists were more than simply strings of words. It seems reasonable to assume that they were passed around among friends, who read them as a type of "magazine." We have no way of determining the proportion between those who studiously read the vocabulary list pages in order to learn new words needed for their work and those who read them for their content and observations of life. The examples studied here suggest that tongue-incheek descriptions of life's vicissitudes were not uncommon, as were criticisms and, occasionally, warnings about the pitfalls of Chinese society. When vocabulary lists are reprinted in contemporary times, they are read and appreciated mostly for their social observations and descriptions. ${ }^{20}$ In this and the 
following chapters, our emphasis in discussing vocabulary lists is on discovering their social and cultural commentary, as a way to comprehend the thoughts and feelings expressed in China's pingmin culture.

\section{More Vocabulary Lists}

Another example of a vocabulary list in my collection is the volume Various Words Offered to the People [Kuanzhong zazi 欵眾雜字]. The copyist did not date this work, but we can assume it was written during the late Qing period, possibly in South China, mostly because a few particular characters appear in the book. The word for "officials" [guanya 官衙] was common before the Republic in 1912, and the book refers to the government office as a "yamen" 衙門, a type of office that was abolished when the Qing dynasty fell in 1911 (although popular usage continued to refer to government offices as yamen even into the Republican period). Also, the word “mansion" [dasha 大廈] came into use in the mid-18oos in South China, later spread to the north, and is now used throughout the country. The paper used for this book has a soft clothlike quality, which I associate with the late Qing rather than the Republican period. The copyist's control of the brush is better in this example than in the previous one. ${ }^{21}$

We have some information about the person who copied it: Guo Changyun 郭長雲, who added the word "copied" [ $j i$ 記] after his name. At some later point, his relative Guo Shengkui 郭生魁 wrote his name and indicated his ownership of this particular volume by adding the word "recorded" [ jishu 記書] next to that of the original copyist on the front cover. The color of the ink differs between these two names, as does the calligraphy.

The first fifteen pages are devoted to lists of plants and animals, minerals and metals. But this text also includes words pertaining to government, family structure, and social and sexual relationships. The phrases in these sections carry a tone of moralizing and reinforcing conventional morality.

The second Mr. Guo also wrote some words on the last page of the book, which likewise stressed morality and responsibility. He then added a sevenword poem [qiyanshi 七言詩] on the final page, which reads:

observations of Qing-period social conditions is Zazi sudu 雜字俗讀 [Reading Popular Vocabulary Lists] (Ji'nan: Qilu shushe, 2010).

21 Various Words Offered to the People [Kuanzhong zazi 欵眾雜字], a text of thirty pages was purchased in Beijing in August 2007. It is $5^{-1 / 5}$ in $(13.97 \mathrm{~cm}) \mathrm{h} \times 4^{3 / 4}$ in $(12.06 \mathrm{~cm}) \mathrm{w}$. This is a handy "pocket" size. This text is also discussed in Chapters 2 and 3 . 


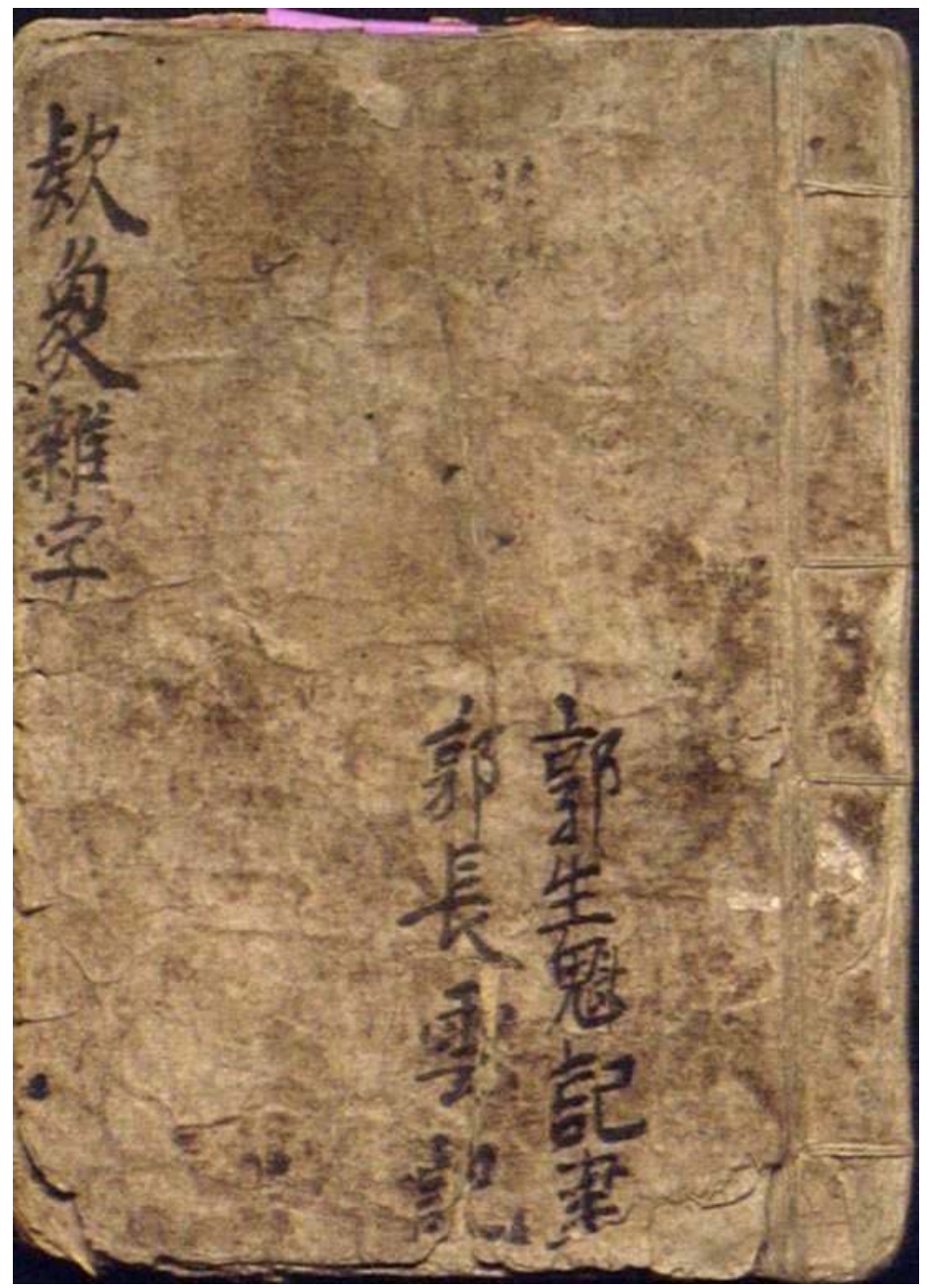

FIGURE 1.7

Various Words Offered to the People [Kuanzhong zazi 欵眾雜字], Cover. On the cover are the names of two members of the Guo family: Guo Changyun 郭長雲, who added the word "copied" [ji 記] after his name, and his relative Guo Shengkui 享生魁.

PHOTO BY AUTHOR 
The three mountains and the flowing rivers are divided by fields

Between heaven and earth are human beings;

Man is the most spiritual of all beings,

Thus he should be continually nurtured.

Sanshan liusui yifentian,

Tiandixianglian zairenjian;

Renwei wanwu shouzhiling,

Ruoyang lianfei yichangkong.

\section{三山流水壹分田, \\ 天地相連在人間; \\ 人為萬物首之靈, \\ 若養煉廢一常空.}

The addition of a poem to this manuscript book by the younger (I assume he was the younger of the two) Mr. Guo makes it more interesting. His calligraphy is not as practiced and is of lower quality than that of the elder Mr. Guo (which colors my assumption about their ages). If this poem accurately reveals something of the younger Mr. Guo's personality, it is that he was a person of conventional morality who enjoyed composing a little poem now and then. Although accepting conventional morality can be the sign of a contented person, as explained below, the younger Mr. Guo shows us that he was not, as some self-righteous people can be, a boringly contented person.

Like the manuscript discussed above (A List of Characters ...), this vocabulary list (Various Words Offered ...) deals with the themes of morality and proper behavior. In the text on sexual relationships, the author assumes the reader is a young man seeking a female partner. Virtually all the written materials in my collection (except those on fortunetelling) assume that the reader is male, so the advice and suggestions therein are directed toward males. This assumption on the part of the author is in accordance with my assumption that the lists were used most often by young men attempting to improve their chances of finding work.

The section on sexual morality (p. 21) reads:

A diligent lad will not imbibe, but be stable in his life

There is no profit in being covetous, if you give in to your [sexual] desires you will harm your own body

First, make a good match, there is no need for a forced marriage

It is not good to be promiscuous, since it will shorten your life and harm society. 


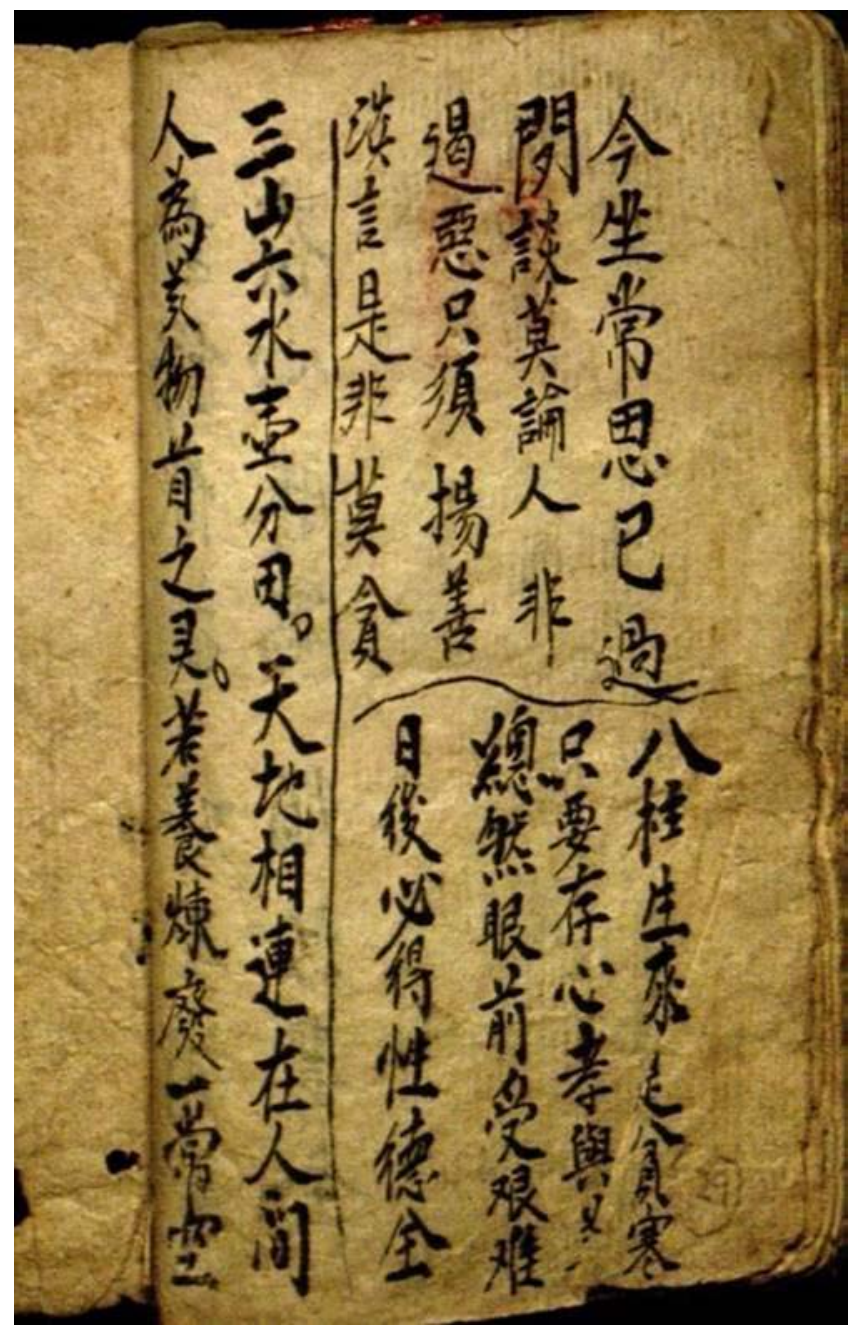

FIGURE 1.8

Various Words Offered to the People [Kuanzhong zazi 欵眾雜字], page 29, Poems. This page shows poems written by one of the Guo 郭 family expressing his acceptance of conventional morality. The poem on the lower right-hand side on page 29 begins, "Man is born by fate to be poor" [Bagui[gua] shenglai shipinhan 八桂[掛] 生來是貧寒]. The phrase reflects its author's assumption that this is a general truism, and it was no doubt true for him.

PHOTO BY AUTHOR 


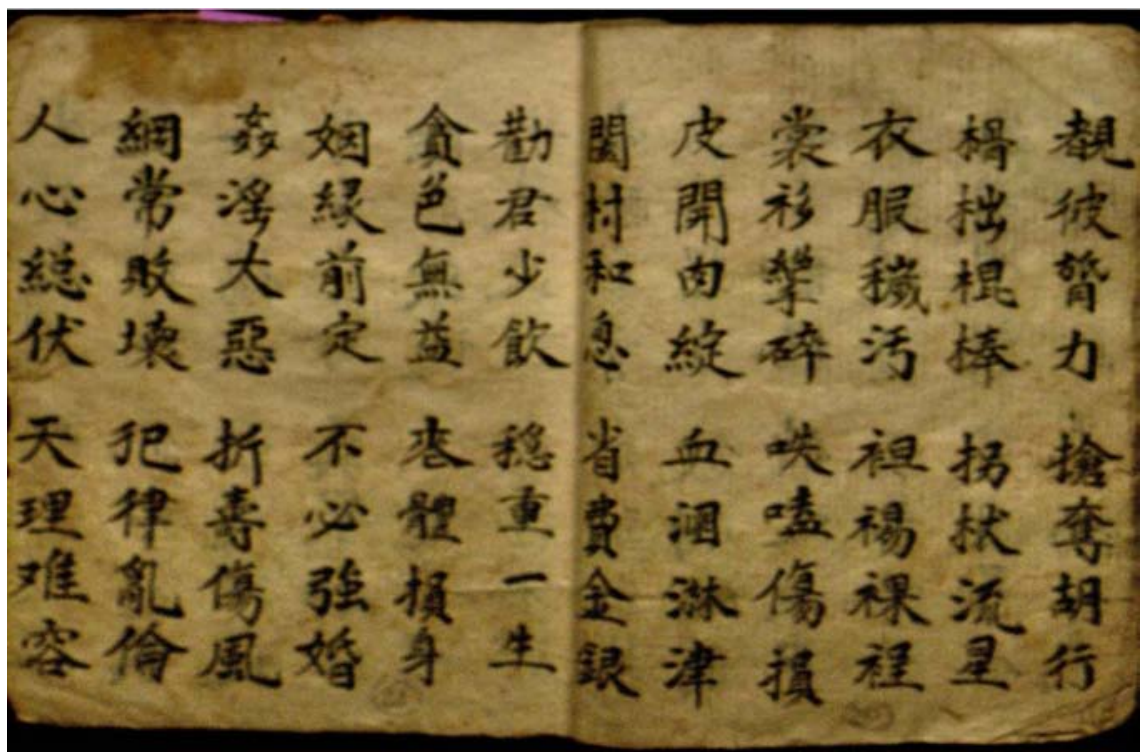

FIGURE 1.9

Various Words Offered to the People [Kuanzhong zazi 欵眾雜字], pages 20 and 21, Sexual Morality. These pages deal with sexual morality for young men as they move about in society. The exhortation to boys and young men begins, "Don't steal or do bad things. Don't wear dirty clothes. Cover your body" [Du bi x li. Qiang duo hu xing. Yi fu hui wu. Tan xi luo cheng 覩彼口力, 搶奪 胡行, 衣服穢污, 袒裼裸裎]. These admonishments would not be given to sons of the well-to-do or the educated elite. The instructions in the text show that it was aimed at the working-class youths. рното вY AUTHOR

\author{
Qinjun shaoyin, wenzhong yisheng \\ Tanse wuyi, $\mathrm{x}$ tisunshen \\ Yinlu qianding, bubi qianghun \\ Jianyin dae, zheshou shangfeng \\ 勤君少飲, 穩種一生; \\ 貪色無益, 口體損身. \\ 銦綠前定, 不必強婚; \\ 茹淫大惡, 折壽傷風.
}

The text on sexual morality unsurprisingly recommends following socially conservative standards of behavior. The majority of common people in China, as in most societies, were not inclined by nature to challenge established mores. Happily, for us, the younger Mr. Guo added a second poem, which was very revealing about his own station in society and his philosophy on life. The poem is simply written, using words in common parlance. It begins (p. 30) with a 


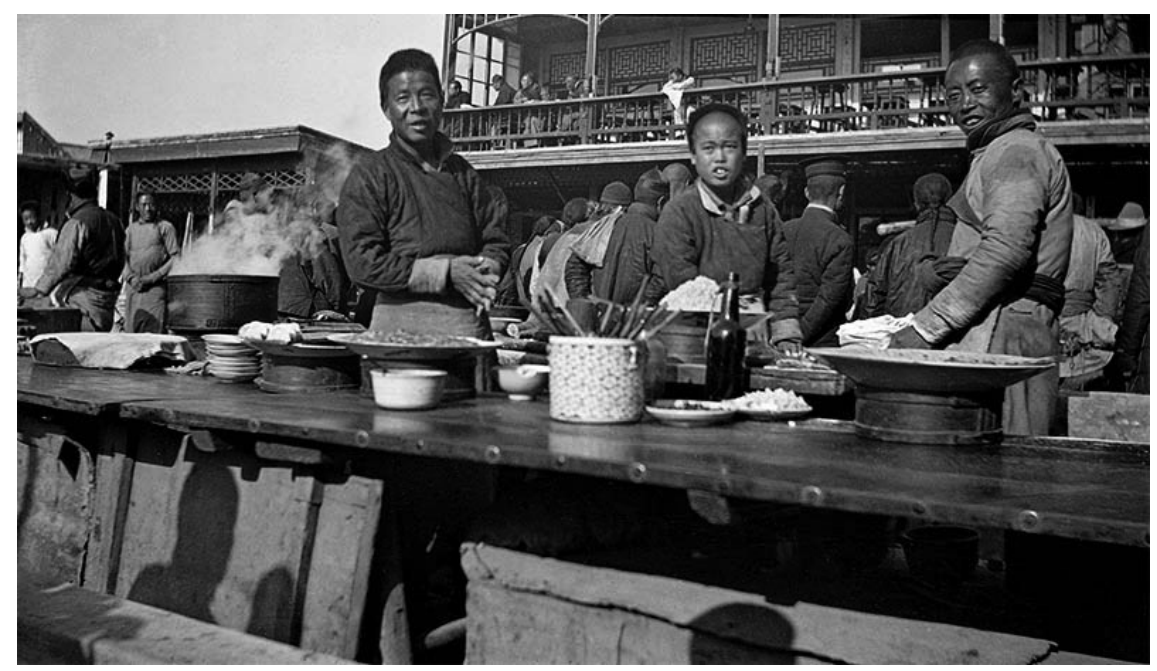

FIGURE 1.10

Street Vendors. Members of the common people [pingmin 平民] here run an outdoor food stand in Beijing in 1913. They would never get rich and dealt all day with passersby on the streets. Their smiling expressions show that they aimed to attract customers and serve them cheerfully.

STREET VENDORS, BEIJING, 1913; PHOTO: WILliaM LEETE; RESTORATION AND PRINT (C)2O16 WILLIAM MORSE. USED BY SPECIAL PERMISSION

mistake, in which the younger Mr. Guo writes bagui 八桂 [eight cinnamon trees], when he meant to write bagua 八掛 [eight trigrams], which I translate as "fate."

Man is born by fate to be poor,

His only hope is to keep piety and respect in his heart;

What he must face is to endure hardship,

At the end of the day, he must have his virtue intact.

Bagui shenglai shipinhan

Zhiyao cunxin xiaoyushan

Zongran yanqian shoujian'nan

Rihou bide xingdequan

八桂生來是貧寒,

只要存心孝與善;

總然眼前受艱難,

日後必得性德全. 
This poem shows that the younger Mr. Guo had only a little beyond a basic education, enough to write a poem, though not an especially accomplished one. He also tells us that he came from a poor family, as probably did most of the people he knew. Life was hard for him, as he expected it was for most people. But this second poem indicates that he accepted the message on sexual morality in this vocabulary list and made it the central message of his second poem. Because of the correlation of the book's message on sex for young people and this second poem, we can conclude that the younger Mr. Guo read and likely studied this vocabulary list. ${ }^{22}$

\section{Grappling with Fate}

A lively religious culture flourished throughout China between $185^{\circ}$ and 1950. Since their very beginning, the Chinese people identified deities and suprahuman forces that influenced all existence. Ancestors became deities, natural phenomena flowed from the actions of heavenly gods, and capricious and malevolent ghosts wandered around on earth. According to commonly accepted beliefs, the world of the gods and spirits resembled the human world. The deities were ranked, much as human beings all held differing social and economic ranks, while vagabond ghosts flitted around at the edge of organized spirit society, just as humans on the lowest economic rungs of the social ladder existed the best they could in a community of fellow humans who showed little tolerance for them.

The indigenous deities in popular religion held complete sway in the minds of most Chinese during this time. The bodhisattvas in popular Buddhism had pedigrees that could be traced back to India, but by the late Qing they had become Chinese-style deities, often with a ranking integrated into the native Daoist pantheon. The hierarchy of Daoist gods usually excluded life that was lesser than human life, such as snakes, animals, and insects (unlike the Buddhists, who should revere all animate life). But the Daoist gods were concerned with all facets of human fate, from the length of one's lifespan to the suffering that might be imposed after death. From the minor inconveniences of daily existence to the need for help as one experienced major life events, Daoist deities protected humans and repelled troublesome lesser ghosts. We

22 The vocabulary lists reveal much more information, and the topic merits comprehensive study. For an example of a scholar reproducing a vocabulary list, see Wang, Ming-Qing shehui wenhua shengtai, 258-262. 
encounter the Three Officials and the other Daoist deities again in Chapter 8, where their position in the Daoist pantheon is placed in the context of how they were viewed by the common people.

Fortunately for Chinese people in the late Qing and Republican period, even those who were illiterate, religious practitioners were available who knew how to contact the gods to enlist their help. Holy altars abounded in both cities and the countryside. Temples [miao 廟] and shrines [ $c i$ 祠] were everywhere, and even informal meeting halls or private dwellings might have an altar. Private halls might have an altar [tan 壇] tended by someone who could be in communication with the gods. The people who managed these venues were specialists who often relied on written texts as guides to the prayers they would chant or the magic charms they would write.

Many religious practitioners, like the common people they served, had only a basic education and often had only bare literacy. Many had learned enough to be able to read the religious texts and manuals needed to conduct rituals. Even for them, it was the written texts that allowed one to properly summon the gods, to worship them, and to ask for their help. The practitioners, with their ability to read the chants and write the talismanic charms, were always ready to be commissioned by the public to communicate with the gods. ${ }^{23}$

The Chants of Repentance to the Three Primes [Sanyuan fa chan 三元法 懺], a manuscript book in my collection, is a ritual text [keyiben 科儀本] for a popular Daoist (and Buddhist) practice of reciting chants [chan 懺] to atone for past transgressions and to ask that the power of the deities be extended to help the petitioner. ${ }^{24}$ The Three Founders [Sanyuan 三元] mentioned in the title

23 Many scholars accept the idea that these religious practitioners were marginalized people, looked at askance by both the common people and the literati alike. Although the wandering Buddhist monk [hexiang 和向] or Daoist ritual master [ fashi 法師] was the subject of many jokes and scandalous stories, I see them as members of the common pingmin class of people. More recent studies by scholars show that both the literati and the pingmin utilized the services of these people when necessary. An excellent study citing many cases of such practices is Jeffrey Snyder-Reinke, Dry Spells: State Rainmaking and Local Governance in Late Imperial China (Cambridge: Harvard University Asia Center, 2009). See also Liu Yonghua 劉永華, “Daojiao chuangtong: shidafu wenhua yu difang shehui: Song Ming yilai minxi sibao Zhou gong chongbai yanjiu” 道教傳統, 士大夫文化與地方社會: 宋 明以來閩西四保郮公崇拜研究 [Daoist Traditions, Gentry Culture, and Local Society: Research on the Master Zhou Cult of Sibao in Western Fujian since the Song and Ming Dynasties], Lishiyanjiu 歷史研究 [Historical Research] 3 (2007). How local communities interact with their local religious institutions in China is examined in Philip Chesley Baity, Religion in a Chinese Town (Taipei: Orient Cultural Service, 1975).

The text of Chants of Repentance to the Three Primes [Sanyuan fa chan 三元法懺] of 
are also known as the Three Officials [Sanguan 三官]. For some Daoists, the liturgical calendar is divided into three segments, with each segment governed by one of these deities. The three areas of human existence controlled by each official are heaven [tian 天], which grants happiness and determines the life span [sheng 生] of humans; earth [ $i$ 地], which controls life on earth and deals with death [si 死]; and water [shui 水], which can ward off evil influences and deals with the difficulties of life [ $k u$ 苦]. Some scholars believe that the Three Founders represent the earliest objects of worship for the Chinese because, without these three elements, life could not be sustained. Over the centuries, these three deities (or stars) were given honorific titles such as the Three Great Imperial Officials [Sanguan dadi 三官大帝] and the Three Imperial Officers [Sanguan dijun 三官帝君].

A handwritten book of three volumes totaling forty-seven pages and bound together in one volume in my collection is titled Repentances to the Supreme Three Primes to Forgive Sins [Taishang sanyuan youzui fachan 太上三元宥罪 法懺; also written on the inside pages as Taishang sanyuan miezui miaochan 太上三元滅罪妙懺]. It was copied by someone named Qian Yicheng 淺一誠 in Hengyang, Hunan, in the late Qing or early Republic. He called his studio the Rui Tang 瑞堂. This publication contains the text on pages 4 and 5 :

To revere heaven on the fifteenth day of the first month, we record the instructions to the hundred offices of the Golden Portal offered to assist the people of the world in their record of sins and blessings, and today at the Daoist altar offer up this work.

Tianzungyan zhengyue shiwuri, shangyuanguan zhulu baisi shangyi Jinque chengjin shiren zuifu zhiji; jin ri Daochang fengwei ruyi shiguhuixiang.

天尊言正月十五日，上元天官注錄百司上詣金關呈進世人罪福之籍； 今日到場奉為如意事故回向. ${ }^{25}$

fifty-one pages was purchased in Beijing in January 20o8. It is $9^{1 / 4}$ in $(23.49 \mathrm{~cm}) \mathrm{h} \times 5^{1 / 2}$ in $(13.97 \mathrm{~cm}) \mathrm{w}$.

25 A thorough explanation of the historical development of the Sanguan 三官 is in Zhang Xingfa 張興發, Daojiao shenxianyinyang 道教神仙信仰 [Daoist Beliefs] (Beijing: Zhongguo shehui kexue chubanshe, 2001), 240-244. Because of the similarity between the Three Gods of the Empyrean (Sanyuan 三元) and the Three Officials (Sanguan 三官), these two sets of deities have been conflated in popular understanding, and often the Sanguan are 
This text is fairly standard, consisting largely of praise to the deities, then listing the worries of the common people and asking for the deity's help. The text Repentences to the Supreme Three Primes [Sanyuan fa chan 三元法懺] is almost interchangeable with How to Absolve Guilt mentioned earlier. For example, in the Chants of Repentance, on page 20, the Celestial Worthy of Primordial Being [Yuanshi tianzun 元始天尊] is praised and called upon to summon the Three Officials. He is seen as the source of all learning and the first author of Daoist scriptures. He is praised by the priest, saying,

Yuanshi tianzun, on high, in the limitless universe, who spreads the great [Buddhist] teaching, who makes known the [Daoist] Way, who rules all life, who takes away all worries, who grants happiness.

Yuanshi tianzun, zaishang, wuji shijie, guangyan dacheng, fufa shuodao, yaodu zhongsheng, lizhu kunao, xianling anle.

元始天尊, 在上, 無極世界, 廣演大乘, 敷法說道, 要度眾生, 離諸苦惱, 咸 令安樂.

The Celestial Worthy of Primordial Being is then asked by the priest to address the Zhongguan 中官 [Middle Official], the deity of the earth able to ward off evil and help with life's troubles. This portion of the text begins,

Primordial Worthy, We beg you to ask the Middle Official who controls the earth, and extending to all the holy ones, from this day forward, wherever there are people worried, when the three calamities arise, when the five evils flourish, when the robbers threaten us.

called the Sanyuan 三元. See the basic explanation in Zhu Yueli 朱越利, ed., Zhongguo daojiao gongguan wenhua 中國道教宮觀文化 [Temple Culture in Chinese Daoism] (Beijing: Zhongjiao wenhua chubanshe, 1996), 284-286. Conflation of the two is mentioned in Zhang, Daojiao shenxian xinyang, 242; in Kubo Noritada 漥德忠, Dōkyō no kamizami 道教の神神 [The Deities of Daoism] (Tokyo: Hirakawa shuppansha, 1986), 158. Mentioned in the text above is Repentances to the Supreme Three Primes to Forgive Sins (Taishang sanyuan youzui fachan 太上三元宥罪法懺; also written on the inside pages as Taishang sanyuan miezui miaochan 太上三元滅罪妙懺), in three volumes, total of forty-seven pages. It is $9^{3 / 4}$ in $(24.76 \mathrm{~cm}) \mathrm{h} \times 81 / 2$ in $(21.59 \mathrm{~cm}) \mathrm{w}$. This size makes it easy for it to be placed upon an altar and read from. It was purchased in Beijing in March 2009 . 
Yuanshi tiancun, fugao Zhongyuan diguan, ji zhu shengzhong, zijin yihou, tianxia, ruo yourenming, buan, sanzai jingqi, wudu xingxing, daozei qinling.

元始天尊, 復告中元地官, 及諸聖眾, 自今以後, 天下, 若有人名, 不安, 三 災競起, 五毒興行, 盜賊侵凌.

On the second to last page of the Chants of Repentance, the copyist gives his name as Wang Shuxiang 王恕鄉 and tells us he copied the book in 1909, in the second month of the first year of the Xuantong era [Xuantong jiyou yuannian eryuezhong wangerri chaocheng 宣統已酉元年二月中望二日抄成]. On the last page, the copyist wrote his name as "Recorded by Wang Shoudao" [Wang Shoudao $j i$ 王守道記]. The name means to "Protect the Dao," thus it is likely the religious or temple name of the copyist. However, on the first page of the book and at many points throughout the text, the stamp "Copied by Wang Youda" [Wang Youda $j i$ 王有達記] appears in black ink. ${ }^{26}$ We can assume that these are all names for the same copyist. At a few points in the upper margin, someone different wrote a few characters, as if making notes on the text. This could indicate that, although Wang copied the text, the priest who chanted the text was a someone else. It is possible that Wang copied that text as an act of devotion or because he was paid to do so.

One manuscript in my collection, Writing Talisman [Shu fu fashi 書符法事], is about the practice of writing out magic charms to keep evil forces at bay and to advertise the protection of the gods. The talisman were magic characters [ $f u$ 符] written on red or yellow paper. They were pasted in various places in the home where protection by the deities was needed, worn on a person's body, or burnt to ashes that were then added to a cup of tea meant to be consumed. They were believed to ward off evil spirits and influences, which would then allow misfortune to be avoided and the body to cure itself of any maladies. When pasted up in the home, they were strong enough to keep evil forces away. By the end of the Qing dynasty, the practice of hanging magic talisman over doorways

26 Seals appear on many of the chaoben in my collection, so the subject of seals, used so commonly by East Asians for centuries, is referred to elsewhere in this book. However, I have not made a particular study of them and translate them here only when the seal text was clear enough to read the characters. An excellent overview on the topic of seals as used in China is Max Jakob Folster, "Introduction to the History, Use and Function of Chinese Book Collector's Seals," Manuscript Cultures 8 (2015). 
or bedchambers or under gate eves or even carrying them on the body was widely practiced among China's common people. ${ }^{27}$

This text was "copied out in the autumn of 1895 during the Qing dynasty" [Daqing guangxu yimo ershiyi nian mengqiuyuezhong huanchaoteng 大清光緒 已末二十一年孟秋月中浣抄謄], by Huang Yongquan 黃湧泉, whose religious name was Huang Daozong [Huang of the Dao Faith 黄道宗]. He embossed his seal prominently on the cover of the book and equally prominently throughout the text. Regardless of which seal was used, his name was followed by $j i$ 記, meaning he was the copyist. He also put one of his seals on the inner fold of every page. He may have done this to gain merit with the deities for having copied the text and certainly to record for other people the fact that he had copied the work. ${ }^{28}$

Huang must have been an active religious performer who likely enthralled his audiences with the religious ceremonies he conducted. Because the stamp he placed on this work does not have a temple name, it is likely that he was an itinerant priest, possibly of the Zhengyi 正一 [Orthodox Unity] school visiting various local temples to conduct his ceremonies and in that way earn his living. That was a common practice among the Zhengyi school clergy since as a rule they did not live together in monastic communities but, instead, lived and traveled in the "real" (non-sacred) world. It is possible he conducted the ceremonies in the open at an altar set up at the periodic markets held in one of China's many market towns [zhen 鎮] or at the home of people who had invited him to conduct a ritual. ${ }^{29}$

27 Useful comments on how the fu charms were understood and used by the pingmin in South China villages are in James Hayes, South China Village Culture (Hong Kong: Oxford University Press, 2001), 49-52. A complete guide to incantations and some related talisman is Zhang Zhenguo 張振國 and Wu Zhongzheng 吳忠正, Daojiao fuzhou xuanjiang 道教符咒選講 [Collection of Daoist Incantations] (Beijing: Zongjiao wenhua chubanshe, 2006).

28 Writing Talisman [Shu fu fashi 書符法事] is a work of twenty-one pages, 8 in $(20.32 \mathrm{~cm})$ $\mathrm{h} \times 5^{1 / 2}$ in $(13.97 \mathrm{~cm}) \mathrm{w}$ and was purchased in Beijing in September 2005. Examples of talisman are given on pp. 18-21.

29 Before 1950, religious shrines existed in great numbers throughout China. It is reported that, as late as 1958, Beijing had 2,730 miao 廟. See Gao Wei 高巍 et al., Mantan Beijingcheng 漫談北京城 [Chatting about Beijing] (Beijing: Xueyuan chubsanshe, 2007), 142. Peter Bol has written that ritual specialists were called in by Chinese families as a matter of course during the Southern Song dynasty. See Peter Bol, Neo-Confucianism in History (Cambridge: Harvard University Asia Center, 2008), 237. 

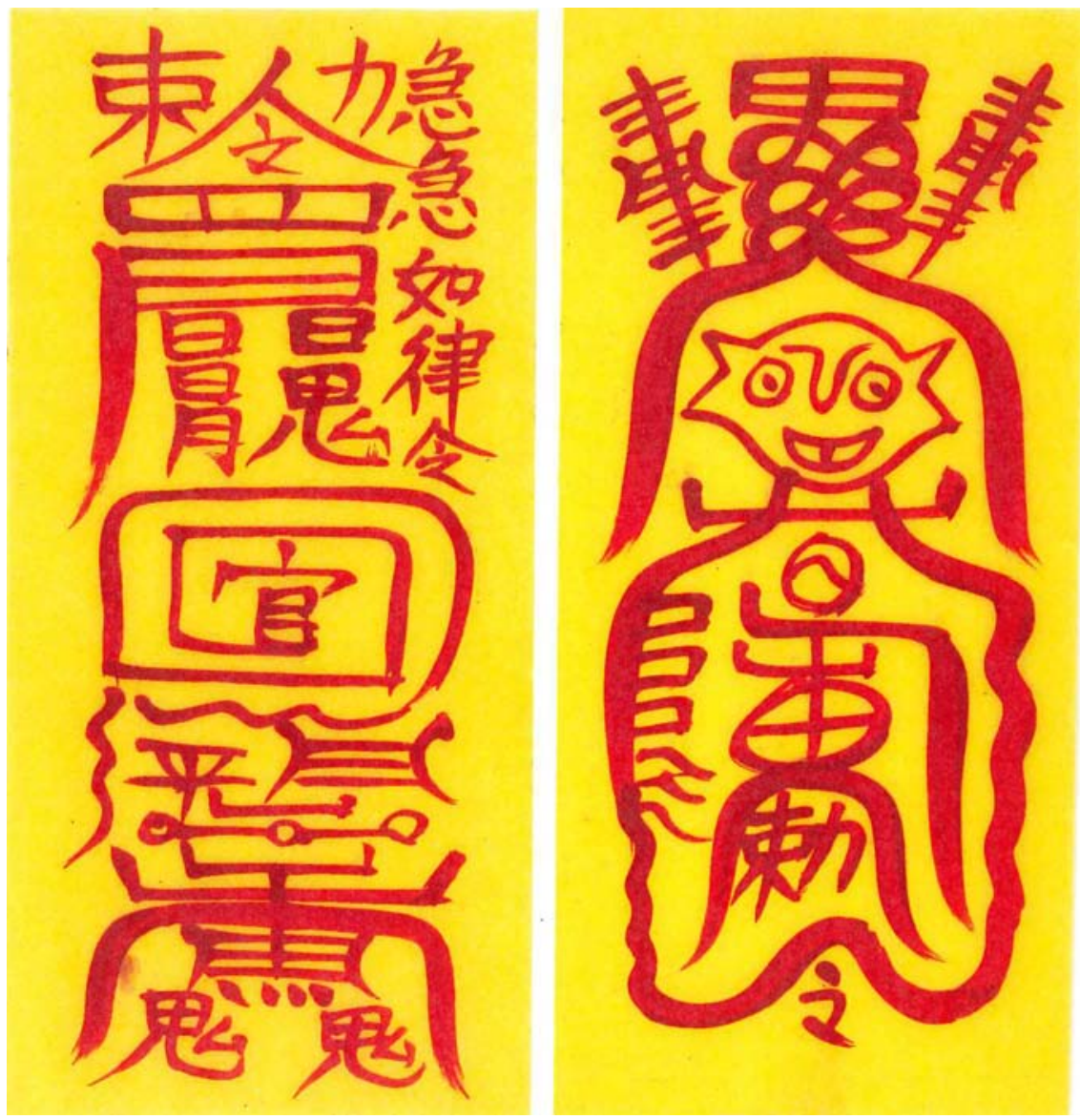

FIGURE 1.11

$\mathrm{Fu}$ 符. Talisman were prepared by Daoist ritual masters and usually written with red ink on yellow paper. On our right is a charm to expel troublesome ghosts. On the left is a talisman protecting against government officials. Bad ghosts and interfering officials were the bane of all the common people in China. From the author's collection.

РнОтО BY AUTHOR

The manuscript discusses the method for writing the magic talisman that were often used in popular religious Daoism. Like Chants of Repentance to the Three Primes, discussed above, this is a ritual text. In order to write a talisman with divine inspiration, it is necessary to ask the deities to descend [jiang 降] to the altar, and this text consists of the chants and invitation to the gods that will bring them to the altar. One of the deities then possesses the priest, who writes a magic talisman while under possession.

As part of one of his presentations, Huang actually wrote some fu while being possessed by a deity. The final pages of this book show the talismans 


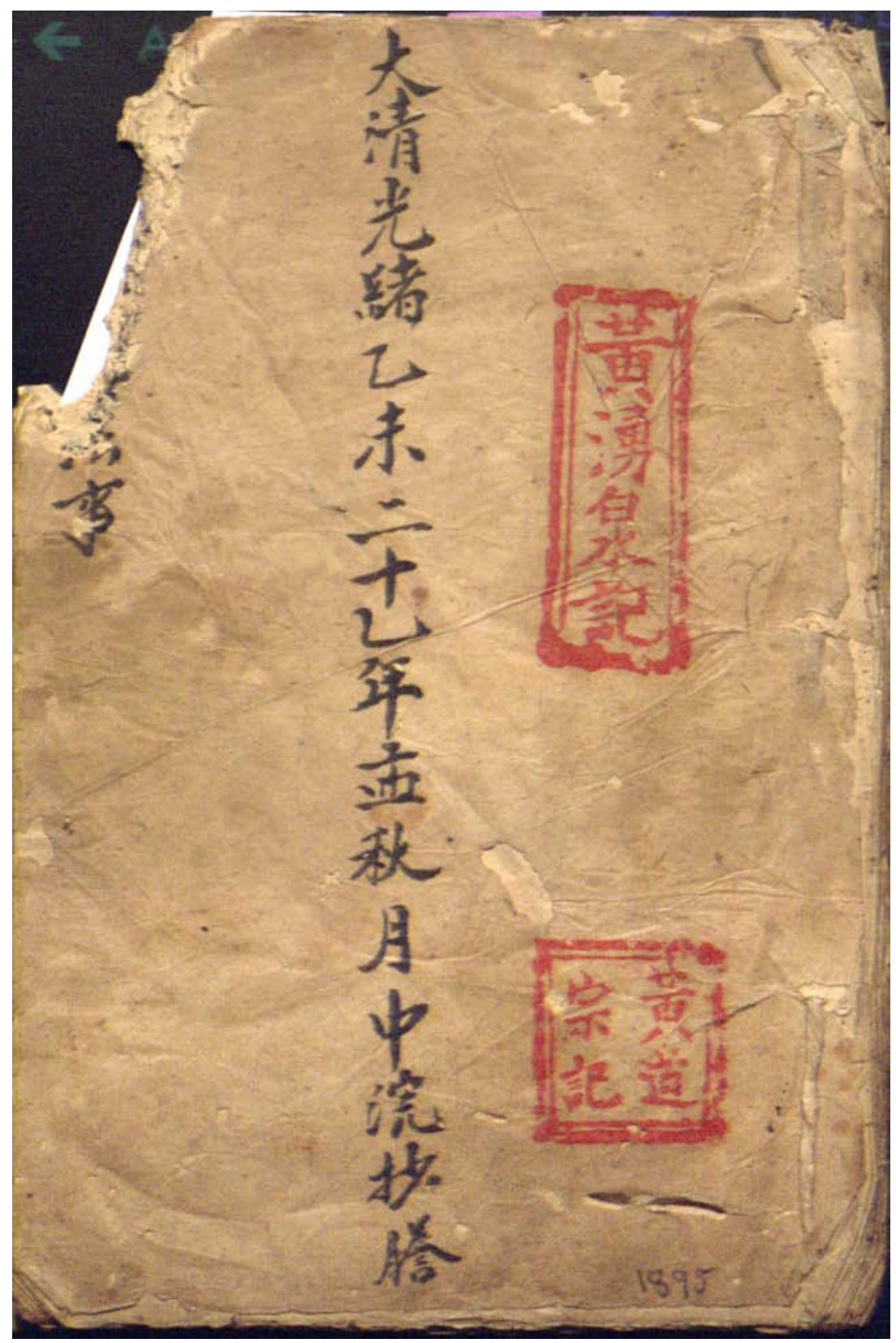

FIGURE 1.12

Writing Talisman [Shu fu fashi 書符法事], Cover. This cover was prepared in 1895. The red seals show the copyist's names; the bottom seal seems to be his Daoist religious name Huang Daozong 黃道宗. An animal (or human?) has taken a bite out of the top left-hand corner. PHOTO BY AUTHOR 
presumably written by Huang while under spirit possession. The writing is large and somewhat wild. These pages also bear his seal. One of the reasons he so carefully placed his seal on the center-fold of every page might have been that this text was a record of that instance of his own possession by a spirit, and he hoped to ensure recognition of this fact and to certify the authenticity of those pages. A powerful performance of his spirit possession was likely to bring in a higher amount of donations from the viewing audience. ${ }^{30}$

Another text is a booklet used by a yinyang master [yinyang shi 陰陽師] titled Riches Bestowed [Qianjinfu 千金賦]. The copier does not identify himself as such, but the contents of the text and the topics on which it concentrates indicate the concerns and expected healings to be offered by a yinyang master. The concerns and powers of this specialist are outlined below. The booklet deals with preventing evil and baleful forces from causing injury and having negative influences. ${ }^{31}$ The evil forces are the baleful stars that can bring harm and the ways of keeping them at bay are set forth in order to keep a proper balance of the forces of yin and yang [yinyang 陰陽], by understanding how the forces of fate as expressed through the eight trigrams affect one's life. The evil forces [sha 繁; p. 9] try to enter wherever they can, whether the home or marriages, to cause sickness to complicate childbirth. As the text says (p. 6), "When dark influences enter the grave site, they are difficult to dispel. When brightness cannot move at will, it encounters only obstacles" [Anxing rumu, nanke, wangfeikong, youqie youfu 暗興入墓, 難攰, 旺非空, 有且有扶].

Some of the elements that have an effect on human beings (pp. 19-22) are given as heaven, water, wind [feng 風], mountains [shan 山], fire [huo 火], earth, and thunder [le $i$ 雷]. The interactions of these forces are outlined is some detail in the text. The author (p. 47) enumerates six deities [liushen 六神]: The North Star Emperor [xuanwu 玄武], the White Tiger [baihu 白虎] of the West, the Flying Serpent [tengshe 騰蛇], the Bewitching One [gouchen 勾陳], the

30 The scholar Gary Seaman has long been interested in Daoist ritual spirit possession. In an earlier study, he discussed how this works in practice: Gary Seaman, Temple Organization in a Chinese Village (Taipei: Orient Cultural Service, 1978). Contemporary instances are described in Lin Wei-ping, "Son of Man or Son of God? The Spirit Medium in Chinese Popular Religion," in Affiliation and Transmission in Daoism: A Berlin Symposium, ed. Florian C. Reiter (Wiesbaden: Harrassowitz, 2012).

31 Riches Bestowed [Qianjinfu 千金賦] is a work of seventy-four pages written in a very good calligraphic hand on poor-quality handmade paper. It is $8^{1 / 2}$ in $(21.59 \mathrm{~cm}) \mathrm{h} \times 5^{1 / 4}$ in $(13.34 \mathrm{~cm}) \mathrm{w}$, a size likely intended for a reference book. This is probably a Republican-era text, and the ink still looks crisp. It was purchased in Beijing in August 2005. This work is also discussed in Chapter 4. 


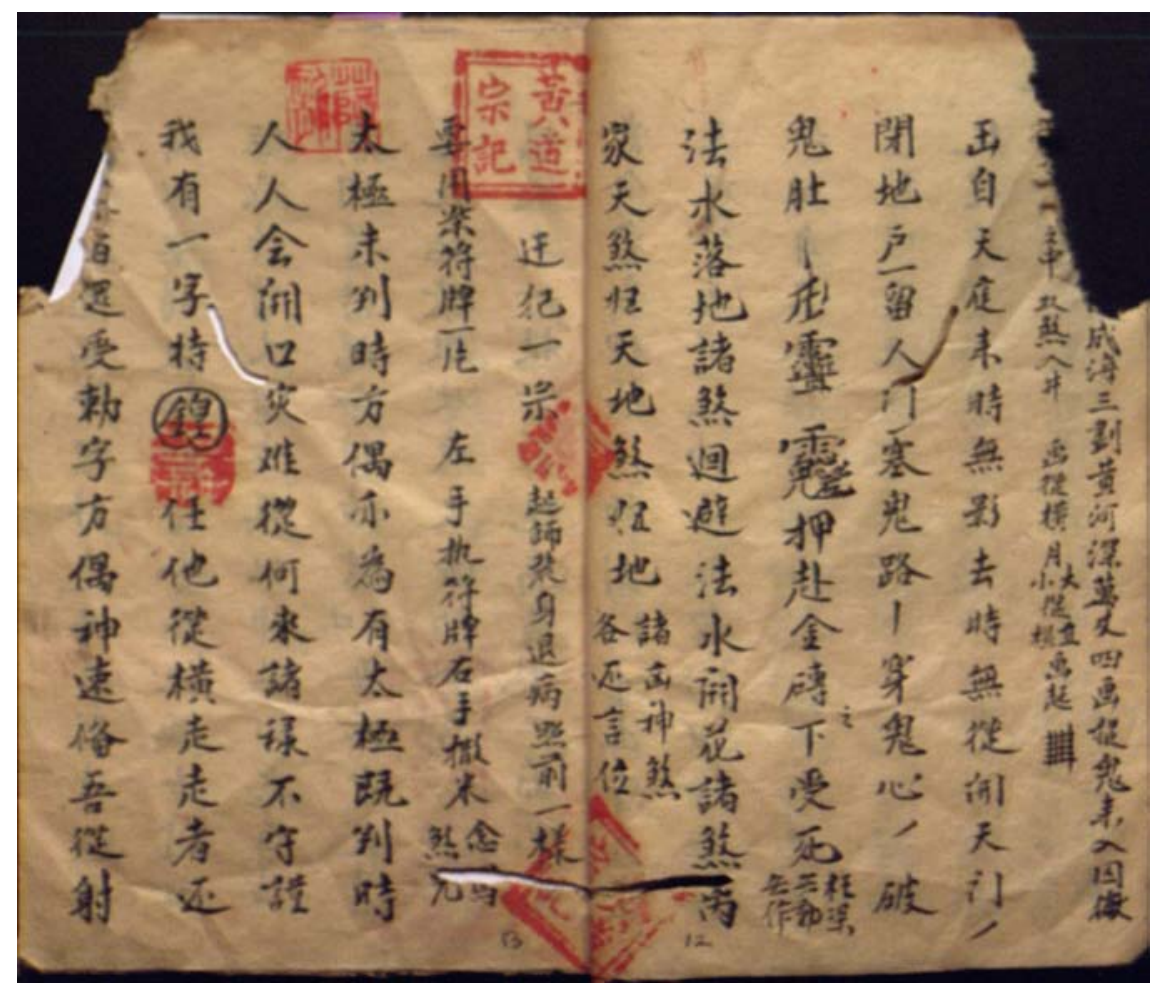

FIGURE 1.13

Writing Talisman [Shu fu fashi 書符法事], Pages 12 and 13, Affixed Personal Stamps. This shows the stamps of ritual specialist Huang 黃, who placed his seal on every page and on the fold between the pages to assert his preparation of the text. Although written in a style not always easy to decipher, most of the talisman in this book are fairly explicit about which deity is being called upon to perform which action against which evil force.

Рното вY AUTHOR

Vermillion Bird of the South [zhuque 朱雀], and the Azure Dragon [qinglong 青龍] of the East. Each of these is a star, said to represent generals and officials from the ancient Yin dynasty (1600-1046 BCE).

Throughout, the text offers sections (pp. 27-28) designed to "help the reader distinguish good and evil” [banren xiangmao meie 辦人相貌美惡]. At a few points, the text encourages the reader to follow the advice it gives as a way of getting to know themselves and their fate. It says (p. 12), "Seek out the astrologer. After being examined, you will know about the strength of divination and how to avoid the inauspicious days" [Qiuzhanzhe, jianhou, zelingshi bichengxin, hefangziri 求占者, 監後, 則靈筮必誠心, 何妨子日]. The text further claims (p. 28) that "[The principles for] gaining inner resolve [to be better] are all here [as revealed in the text]" [jueding xinzhong changhe ci 決定心中常合此]. The 


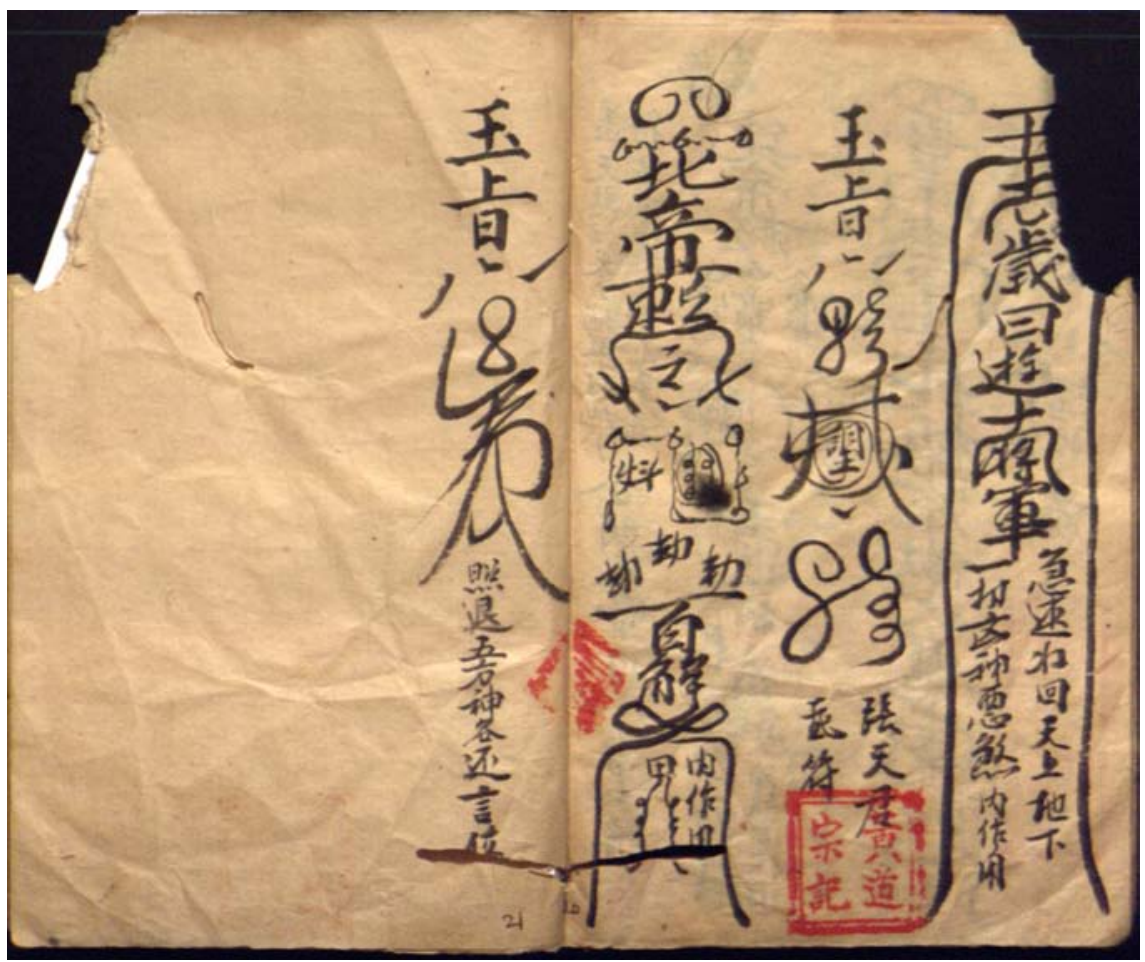

FIGURE 1.14

Writing Talisman [Shu fu fashi 書符法事]. Pages 20 and 21, Instructions from the Deities. These show characters written by Huang Daozong 黃道宗 while being possessed by the deity. These are talismatic characters, written in a wild and oversize hand. Additional comments on the same pages were added later in a more controlled style of writing.

Pното BY AUTHOR

text summarizes its arguments (p. 27) as follows: "First know your horoscope, then understand your nature. To understand human intentions, you must use the Classic [Book of Changes]" [Xianshi guamiming, hou shi xing. Zhi renxindi, zhenyao jing 先識掛密命, 後識性。知人心地, 真要經].

The person who used Riches Bestowed would have been convincing as a yinyang master giving advice to dispel the malevolent influences on his client. The text is sweeping in its coverage of the host of spirits, ghosts, and baleful forces that roamed unseen in the sky above and in the human world on earth. The yinyang master was called upon to decide auspicious days for marriage, a funeral, moving, and so on. Many people afflicted with an illness believed that the cause was a disturbed or angry spirit. Combining ideas of the influence of the natural world on human actions [ fengshui 風水], the power of star deities, and the calculations of eight trigrams, the service of this category of specialist 


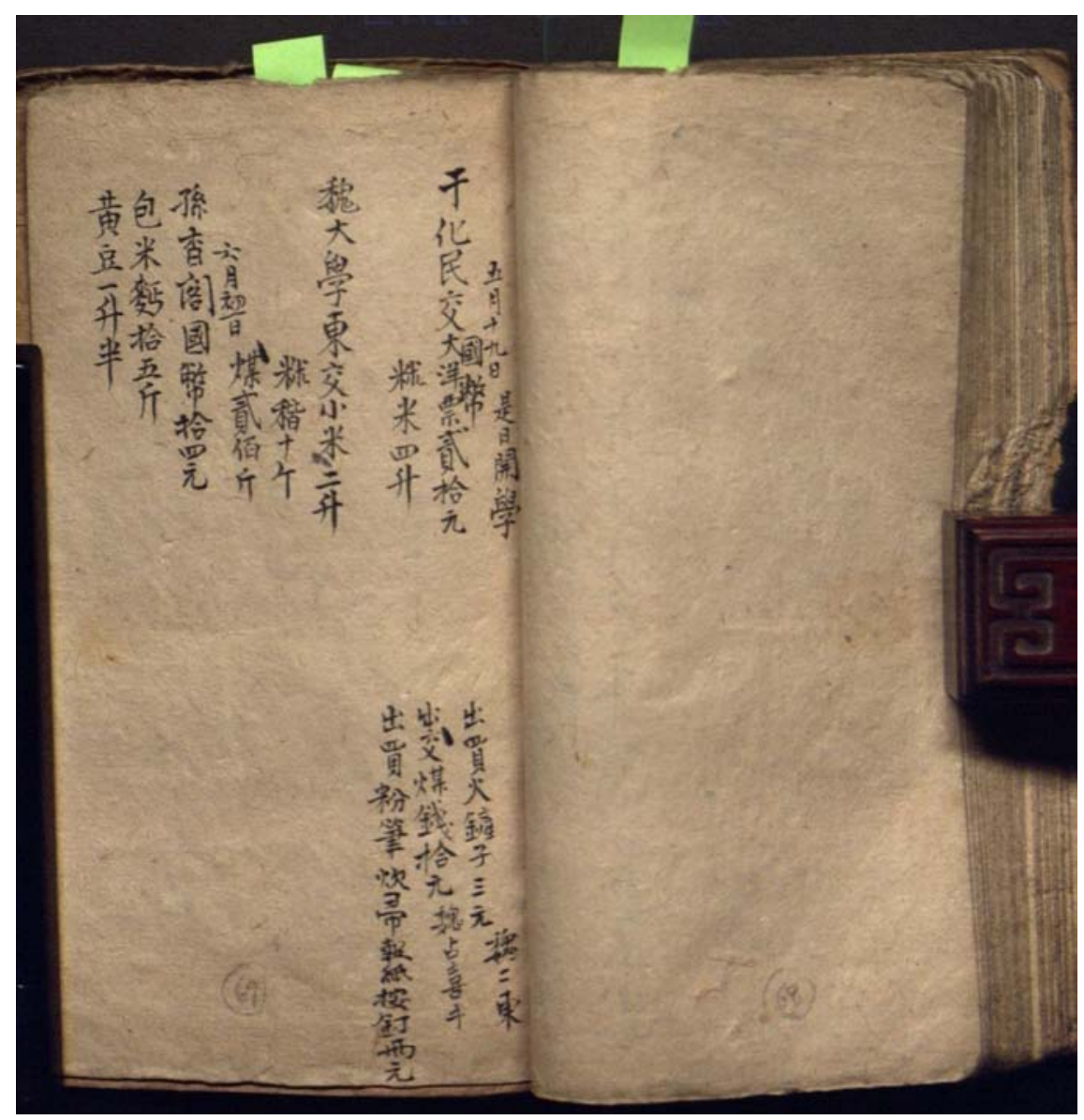

FIGURE 1.15

Riches Bestowed [Qianjinfu 千金賦], Pages 68 and 69, A Teacher's Income. These pages show the income of a schoolteacher, probably teaching in Chaoyang 朝陽, Fengtian 奉天 Province in the early Republic. He received both money and goods. The level of the payments indicate his income was adequate for living but at the level of a typical semi-skilled worker, and that he was clearly in economic terms a member of the common people.

PHOTO BY AUTHOR

was much in demand throughout China, including in both urban and rural areas, mentioned again below.

Not surprisingly, the person who copied this manuscript tells us that he also worked as a teacher in a number of places in his city. At the end of his manuscript, he lists the schools where he taught. This information is an illustration of a point mentioned earlier: these chaoben should be considered notebooks, written (or copied from other sources) for the writer's own reference. These were used by the person who wrote them to earn income. 
One of the places where he taught was the Sun Clan Temple [Sun xiangge 孫香閣], and it appears this clan school was located on Sun Family Bay Road [Sunjiawan jie 孫家灣街]. ${ }^{32}$ It was a well-accepted practice in China to have a school for local and clan boys at a clan temple. One of the other schools where he taught was the Huamin 化民 School, located on Huamin Street. He also taught at a school called Wei University [Wei daxue 魏大學]. Along with the names of the schools where he taught and the names of some of the streets in his city [Huigongjie 惠工街, Chongdejie 崇德街, Xiangjie 祥街, Yonganjie 永安街, etc.], the owner of this text wrote a few of his accounts. He wrote (p. 69):

School opened on May 19. From Huamin I received 20 yuan in foreign money [dayang piao 大洋票], in national currency [guobi 國幣], and 4 jin (a jin was roughly equal to an American pound) of millet. I purchased a shovel for 3 yuan, handed over 10 yuan for coal, then bought chalk and a broom, and took out a newspaper subscription for 2 yuan.

Wuyue shijiuri, shiri kaixue. Yuhuaminjiao dayangpiao[guobi] ershi; shimu sisheng. Chumai huochanzi, sanyuan; chujiaomei, qian shiyuan; chumai fenbi, chuizhou; baozhi anding, liangyuan.

五月十九日, 是日開學. 于化民交大洋票[國幣]貮拾; 㯟米, 四升. 出買火 鏟子, 三元; 出交煤, 錢拾元; 出買粉筆, 炊帚, 報紙按定, 兩元.33

32 More than one location in China was called Sunjiawan. The most likely one here is in Chaoyang, Liaoning Province (at the time called Fengtian 奉天 Province). I reached this conclusion because the market in Beijing where I bought this notebook regularly has materials from Northeast China. The location is given online as: Liaoning sheng, Chaoyang shi, Shuangtaqu xiaxiade yige xiangzhenji xingzhengdanwei 遼寧省朝陽市雙塔區下 轄的一個鄉鎮級行政單位. See zh.wikipedia.org/zh-hk/孙家湾镇/, accessed March 9, 2014. Of course, more work is needed before we can identify the place of origin of this notebook with greater confidence.

33 The terms guobi 國幣 [national currency] and dayangpiao 大洋票 [foreign notes] became common after 1900 and into the early Republican era. These phrases give us a clue to possible dates for this chaoben; probably 1910 to 1930. This phrase appeared in dictionaries compiled in the 1930s. For example, see Mathews' Chinese-English Dictionary (Taipei: Wenyou shudian, 1974), 551. It also appears in more recently published dictionaries, such as in John DeFrancis, ed., ABC Chinese-English Comprehensive Dictionary (Honolulu: University of Hawai'i Press, 2003), 334. Many paper notes issued by the central government between 1910 and 1935 had the phrase written in English "national currency." The guobi was 
About his pay from the Sun Family Temple, the owner of this book wrote (p. 69), "On the first day of June, from the Sun Family Temple I received: 14 yuan in national currency, 15 jin of corn flour, and 1.5 sheng (often used for moist or liquid items, was the equivalent of 2 American pints) of soybeans" [liuyue chuyiri, sunxiang'ge, guobi shisiyuan; baomimian, shiwujin; huangdou, yishengban 六月初一日, 孫香閣, 國幣拾四元; 包米麵, 拾五斤; 黃豆, 一升半]. The payment in corn flour suggests that he was living in the northern part of the country, rather than in the south, where payment in rice was more likely. Then, as now, people in North China generally ate fried or steamed bread. Corn flour was common in Northeastern China.

He must have been an interesting teacher for the boys, wrapped up in the idea of baleful forces lurking about and even causing illness in human beings (as he writes at one point), but he wrote well, showing experience in calligraphy. Through his jottings at the end of the manuscript, he left enticing clues about his life, his work, and his modest standard of living. We can conjure up an image of this man as someone with a good amount of formal schooling, living in a community of people not especially Westernized or sophisticated, and probably providing elementary education to local children in writing and some of the classics.

At some point in this manuscript's history, possibly in the late 1930s or 1940s, it came into the possession of someone who was willing to follow the principles outlined in the text as a way of realizing some gain. This person wanted to believe that the spirits would help him if they were properly honored. He even wrote a motto (p. 1), “The benefit of hard work" [shike zhi yi 噬嗑之益], on the inside front cover (in pencil, and up-side-down in relation to the rest of the text that follows; shike 噬嗑 is a colloquial expression meaning "hard work" but, more literally: "stop chatting and get to work!"). Alas, this person's troubles continued even after following the text's instructions. In a disappointed tone,

a silver-based currency note established in 1910 and abolished in 1935. It is described online as: "This indicates the national currency of China. It was established in 1910 as the basic unit of currency, and was called "yuan." It was abolished in 1935 by the Nationalist Government as a silver-based currency, in favor of the Legal Currency ' $f a b i$ ', and it was called the National Currency 'guobi.' 指中国国定的银本位货币。清宣统二年 (1910 年), 规 定国币单位, 定名曰“圆”. 1935 年国民党政府废止银本位币, 采用法币, 沿称国 币." See http://www.baike.com/wiki/\%E5\%9B\%BD\%E5\%B8\%81/, accessed May 15, 2014. Photos of many paper notes from the Republican era currently available in China's markets, along with typical selling prices for them, are in Gudong sucha shouce zhibi 古董速查 手冊紙幣 [Quick Guide to Old Currencies] (Changsha: Hunan meishu chubanshe, 2010), 61-184. 
the possessor of the book abandoned it, writing, "My friend gave this book to me, but it hasn't been of any help" [Youren zengshu, wode, ci you wuliyi 友人贈 書, 我得. 此有, 無利益]. ${ }^{34}$

\section{Dealing with Social Conventions}

Many Chinese, whether they worked in city or the countryside, had only basic or functional literacy. The majority could probably read and write their names as well as recognize basic characters used in shop signs and local place names. No doubt a number of people were functionally literate within their occupation, especially shop owners, salesmen, and traders. Certainly, many religious specialists, fortunetellers, and practitioners of traditional medicine could be considered literate, at least by the people around them.

In the 1980s, several Western scholars became interested in determining the rate of literacy in late Qing and Republican China. Many reached the conclusion that, in the late Qing dynasty, at least 30 percent of China's population had some degree of literacy, and this figure is widely accepted for the early Republican era as well. ${ }^{35}$ Scholars such as Evelyn Sakakida Rawski and Paul Ropp accept these estimates. Cynthia J. Brokaw performed a survey of the various estimates and has a thorough discussion of the different estimates that might be drawn. Benjamin A. Elman compares the traditional examination system for clues about how it affected literacy. Even Mao Zedong, writing in the 1930s,

34 When I initially bought this book, I classified it as a fortuneteller's notebook but now see it as having belonged to a yinyang master who also taught school.

35 See Rawski, Education and Popular Literacy in Ch'ing China 23:241 n. 1; Paul S. Ropp, Dissent in Early Modern China:Ju-lin wai-shi and Ch'ing Social Criticism (Ann Arbor: University of Michigan Press, 1981), 31-32; Benjamin A. Elman, A Cultural History of Civil Examinations in Late Imperial China (Berkeley: University of California Press, 20oo). But estimates of literacy and functional literacy vary from 5 percent to over 5 o percent. For a thoughtful and well-documented consideration of this topic, see Cynthia J. Brokaw, Commerce in Culture: The Sibao Book Trade in the Qing and Republican Periods (Cambridge: Harvard University Asia Center, 2007), 559-568. Broad coverage of the Qing exam system with interesting details are in Yang Xuewei 楊學為 et al., ed., Zhongguo kaoshi tongshi 中國考 試通史 [Comprehensive History of China's Examinations] (Beijing: Shoudu shifan daxue chubanshe, 2004), 3: 349-375. Mao Zedong's estimate is in Mao Zedong 毛澤東, Report from Xunwu 尋烏調查, trans. and ed. Roger R. Thompson (Redwood City, CA: Stanford University Press, 1990), 191. The topic of literacy is discussed in the text below and is also discussed in Chapters 4 and 7. 
gave this estimate of the literate people in the community he examined, and he accounted for numerous categories of semiliterate people in the community.

On some occasions the illiterate and even the functionally literate needed to call upon the services of an educated and more fully literate person. Major life events, such as marriages or funerals were such times. Although the family members organizing the ceremony probably could not always read or write very well, written invitations and scrolls were considered de rigueur for formalizing and solemnizing the occasion. The anthropologist Adam Chau calls the practice of utilizing the power and prestige of the written word to lend authority to an action a "text act." ${ }^{36}$ From the time of the earliest Chinese archaeological finds down to the present day, written characters give importance to events and the information they convey. In the process of organizing ceremonies for major life transitions, Chinese families needed the help of a specialist, both to understand how to perform the ceremonies and to prepare the flowery and formulaic language to be used. Scrolls of poetic couplets were also regular part of these observances.

Marriages and funerals were entwined with the power of the deities, but they were primarily ceremonies involving human beings who were connected by layers of human experiences, disagreements and hopes. Thus the specialists who advised on marriages or funerals also provided advice on how best to avoid problems by adhering to the set practices drawn from the approved traditions. In this category of specialists were those who gave legal advice to individuals who believed they had been wronged. These legal advisors gave practical advice, much as would a marriage go-between, but they also possessed some knowledge of legal practices and procedures.

Individuals who relied on references to written texts for the advice they gave, or who earned an income by writing something for others, were most likely to be holders of at least a xiucai degree. Because of their sound basic education, they could turn to the written materials available as guides to writing proper marriage invitations or a eulogy at a funeral, and they could read the samples of legal cases that circulated among the public. Their calligraphy, as demonstrated in the manuscripts examined here, showed good control of the brush and was of acceptable quality in the market or the schoolroom. Many of these ritual specialists also prepared the matched hanging scrolls, and they wrote the

36 The undeniable power of written words in China, the power of the "text acts" referred to here, is analyzed in Adam Yuet Chau, "An Awful Mark: Symbolic Violence and Urban Renewal in Reform-era China," Visual Studies 23, no. 3 (December 2008). 
formal invitations and notices used in family ceremonies. Because these were literate men in a society where the majority of people had limited literacy, all of those who could read and write with any facility possessed skills that gave them access to a number of professions (ways to make a living). A fortuneteller, for example, could also give medical or legal advice, copy a book, or write letters for others. The people discussed in this chapter should not be seen as professionals who were limited by their skills but, rather, as literate men who could simultaneously engage in a variety of occupations. ${ }^{37}$

As educated people with attractive handwriting, many of the xiucai could also earn income as scribes. Such specialists sometimes set up shop (which could be a small storefront operation called a letter-writing shop [daishufang 代書房] or a simple table set up in the marketplace [daishusuo 代書所]). The letter writers could read letters or documents received by their clients and prepare written responses at their client's request. Because scribes were considered fully literate, they could just as easily be called upon to give advice on any other matters in which consulting a written text was involved, as mentioned earlier, such as Chinese medicine, fortunetelling, and writing legal petitions. ${ }^{38}$

One manuscript book I have that deals with a major life transition is titled On the Foundation of Marriage (This Edition) Free of Mistakes [Hunyuanjiang, wushi 婚元講勿失]. Additional text on the front cover says: "How to Achieve Success" [Shu mao zhi 樞檚志]. ${ }^{39}$ Throughout, the text claims to be laying out everything that must be in place in order to have a successful marriage. For instance, all the stars must be aligned, the proper deities respected, the five elements and the critical eight trigrams all need to be correct. Because spirits and forces abound, every precaution must be taken to correctly carry out each small detail in the planning and execution of the event. The copyist

37 This idea is discussed in Melissa Macauley, Social Power and Legal Culture: Litigation Masters in Late Imperial China (Redwood City, CA: Stanford University Press, 1998), 124125. Legal matters at the local level are studied in Ah Feng 阿風, “Ming-Qing Huizhou susong wenshu de fenlei 明清徽州訴訟文書的分類 [Categories of Legal Complaints in Huizhou during the Ming and Qing]," Huixue 徽學 [Huizhou Studies] 5 (2008).

38 The work of those who wrote letters and invitations is described in James Hayes, The Rural Communities of Hong Kong: Studies and Themes (Hong Kong: Oxford University Press, 1983), 195. For an application of these materials for research purposes, see Wang Zhenzhong, “Chaoben一(xinshu) suojian Jinling dianpu huoji de shenghuo 抄本一信書 所見金陵典舖伙計的生活 [The Life of Pawnshop Clerks in Nanjing Based on chaoben, Written Letters]," Gujiyanjiu 古籍研究 [Research on Ancient Texts] 2 (2004).

39 On the Foundation of Marriage (This Edition) Free of Mistakes [Hunyuanjiang, wushi 婚元講勿失] is a work of sixty-eight pages. It is 7 in $(17.8 \mathrm{~cm}) \mathrm{h} \times 4^{1 / 2}$ in $(11.43 \mathrm{~cm}) \mathrm{w}$. I bought it in Beijing in September 2005. This work is also discussed in Chapters 2 and 3 . 
was no doubt a life advisor and counselor who taught both ritual correctness and the need to propitiate the external forces present in the physical world. He might have also functioned as a yinyang master.

Among the points addressed in the text are those that determine which days and times were auspicious and which were inauspicious for formalizing a match. They are determined in part by understanding that the five elements can align to help or hinder the marriage [wuxing shengke 五行生剋], that marriage should not take place in yang years but can take place in yin years [ yangnian jinhun, yinnian bujin 陽年禁婚, 陰年不禁]. It is crucial to know which days are auspicious [hongshari紅沙日], the directions of the compass that will determine one's fate [ming zaihefang 命在何方] as well as the directions to be avoided [hunyin buke xiangfang 婚姻不可向方]. Until the 195os and sometimes beyond, brides were regularly carried in a sedan chair (palanquin) as part of the wedding ceremony, and this text advises (on pp. 31-32) that the bride even be careful to alight from the sedan chair in the proper direction [xiaqiao fangxiang 下轎方向]. ${ }^{40}$

The text advises adults planning the wedding to know which years are inauspicious and will prevent a good match as well as knowing which star gods to call upon in order to determine the fate of the match [nan nu minghe qiguanlun 男女命合起官論]. On the day of the ceremony, it is important to hang a sacred charm over the marriage bed [jiaqu zhangfang zhenfu 嫁娶 帳房鎮符], and, for this purpose, a number of the magic talisman are given [ $f u t u$ 符圖; pp. 36-39, labeled as talisman illustrations], so that they may be properly copied by a priest or scribe. How to construct the eight trigrams is also explained.

The text I have was obviously used by the fortuneteller, who marked it with red ink throughout to help him quickly find relevant sections. He must have been a good talker and a persuasive conversationalist, skills that all good fortunetellers should have. In an exercise in good marketing, and to boast of his own skills, he wrote his favorite sales pitches in the upper margins of some of the pages. For example, he wrote (p. 62): "This book is completely beneficial, and each word is worth a thousand cash" [shishu jie youyi, yizi zhi qianjin 是 書皆有益, 一字值千金]. On another page, touting his own ability, he wrote (p. 64): "It is easy to gain a thousand cash, but difficult to acquire useful advice" [qianjin yide, haoyu nanqiu 千金易得, 好語難求]. Of course, he could provide good advice.

40 This aspect is on p. 31 of the text. A discussion on auspicious and inauspicious actions in a marriage ritual is pp. $21 \mathrm{f}$. 
The copyist/author who penned On the Foundation of Marriage tells us something about himself, including his address (pp. 2-3) in the Fourth District on the broad open slope, Huo County, Shanxi Province [Shanxisheng, Huoxian, Disiqu, kuanchangpo 山西省, 霍縣, 第四區, 寬常坡]. I wonder whether this means he practiced his trade in the open or the broad hillside was a bit of open land where peddlers set up their stalls and the passing townspeople and laborers kept up a steady stream of foot traffic all day? "Broad open slope" may have been the local term for a sloping hillside where small shops were located. This market town was located in southwestern Shanxi Province, south of the large city of Taiyuan 太原 and also south of Pingyao 平遙, home of the famous Shanxi merchants who controlled long-distance trade and banks in much of eastern China in the late Qing and early Republican era. Pingyao is now a wellpreserved tourist destination, where former merchants' handsome homes can still be visited. The Fourth District designation would have been familiar in the 193 os but not much before then.

More to the point of our inquiry here, he indicates that he is a xiucai. He wrote at the top of one of the pages (p. 46), "A xiucai studying yin and yang will easily burn a lamp's worth of oil" [xiucai xueyinyang, yongyou yidengzhan 秀才學陰陽, 用油一燈盛]. The meaning is that the poor scholar will spend a lot of time and effort learning about fortunetelling in order to make a living. I assume the copyist was describing himself. The point of writing in the margins of the chaoben pages, and this example, is addressed again in Chapter 2.

\section{Legal Issues and Life Events}

When an ordinary person in Qing China had a grievance against another like himself or against someone in authority, he could turn to a legal advisor, known politely as a legal advisor [songshi 訟師] and less politely as an arguer or pettifogger [songguan'er 訟棍兒]. ${ }^{41}$ Such a person had several years of a typical formal education, was literate, and was hired to advise people who planned to bring a legal case against another person or family. He usually was not trained

41 Two comprehensive sources about songshi 訟師 are Macauley, Social Power and Legal Culture; and Dang Jiangdan 黨江丹, Zhongguo songshi wenhua: gudai lvshi xianxiang jiedu 中國訟師文化; 古代律師現象解讀 [China's Litigator Culture: A Modern Explanation of Traditional Legal Masters] (Beijing: Beijing daxue chubanshe, 2005). The backgrounds of the songshi are discussed by Macauley, Social Power and Legal Culture, 111-114; and Dang, Zhongguo songshi wenhua, 144-146. 


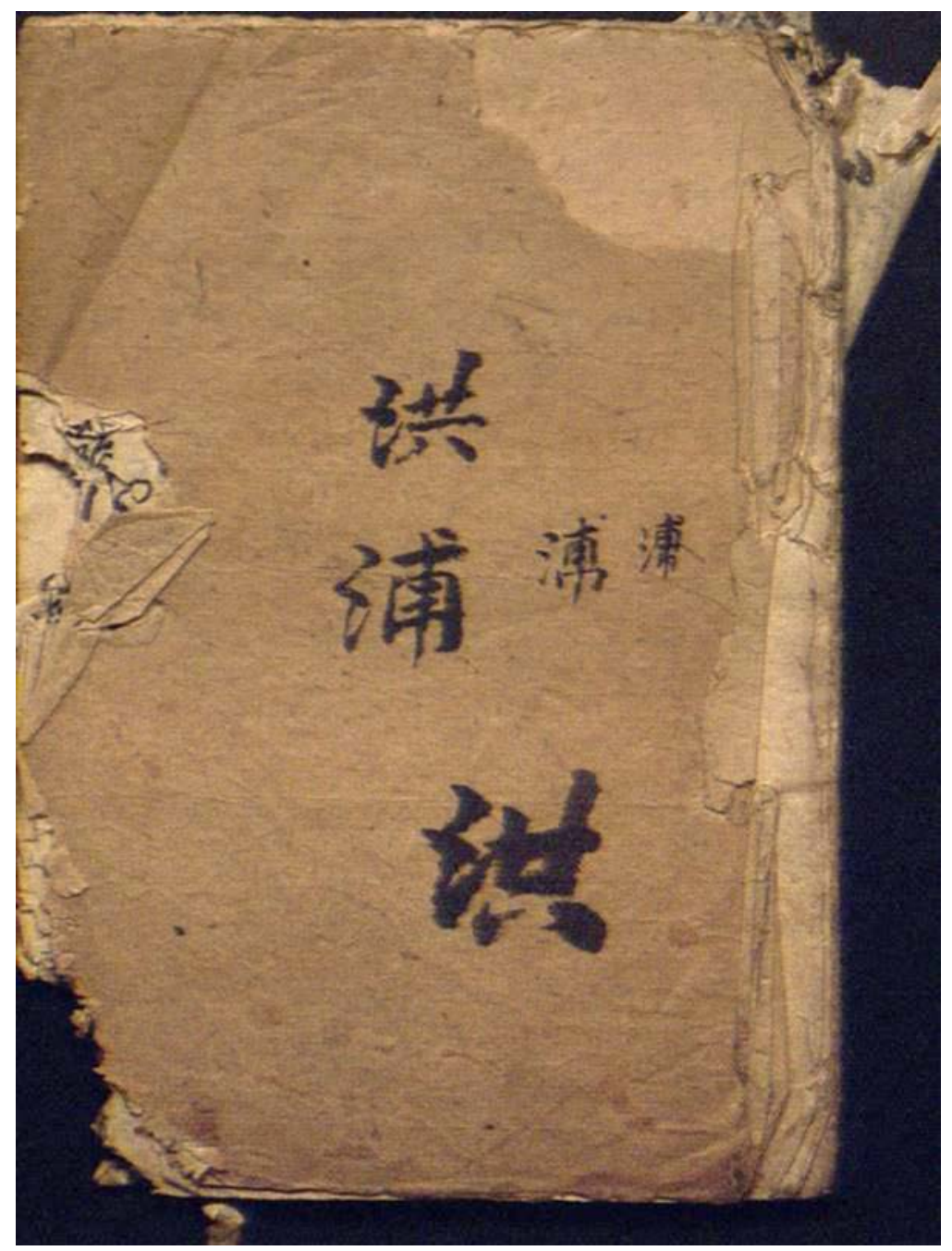

FIGURE 1.16

The Red Shore [Hongpu 洪浦], Cover. This is a manual used by a professional litigator [songshi 訟師], probably a xiucai 秀才, who was also interested in games of chance, as the latter pages describing a game of chance and/or fortunetelling show. His descriptions of criminal cases and their outcomes are abbreviated and clearly taken from other sources.

Рното вY AUTHOR 
specifically in legal matters but developed his knowledge over time through self-study or instruction from someone more knowledgeable. The litigator was likely to be a xiucai. It seems likely that other members of his family also had formal education. The litigator would explain the situation in legal terms to the people who had hired him, and he could explain a strategy for winning the legal case. He would write out the complaint to be presented to the local authorities. In traditional China, those authorities included the local magistrate [zhixian 知縣] and officials associated with the yamen. Like his brothers who offered fortunetelling about the future, the litigator's place of business might be little more than a table set up at a market.

The manuscript book titled The Red Shore [Hongpu 洪浦] is a manual for a professional litigator. ${ }^{42}$ The volume I have deals with marriage cases [hunyin lei 婚姻類]. Sixteen pages are devoted to setting forth six legal cases. In each instance, first, the complaint [ $g a o$ 告] is stated, followed by the formal charge [ $s u$ 訴], and then, lastly, the judgment [panwan 判文, shenyu 審語]. These six cases were likely drawn from published legal cases in the Ming or Qing eras. They are merely brief summaries of each case and its disposition. The names of the people involved are sometimes given, but other information, such as dates and exact locations, are omitted. These texts were used as examples that the litigator could consult in advising his clients. They gave the litigator an idea of the reasoning or logic that would be used to decide the case and perhaps some indication of the precedents that would be consulted by the authorities in reaching their judgment. ${ }^{43}$

42 The Red Shore [Hongpu 洪浦] is $6 \frac{1 / 4}{4}$ in $(15.87 \mathrm{~cm}) \mathrm{h} \times 4^{1 / 2} \mathrm{in}(11.43 \mathrm{~cm})$ w. It has forty-four pages and was purchased in Guilin in September 2005 .

43 A useful discussion of writing legal judgments [panwen 判文] from the Tang era is in Norman P. Ho, "Law, Literature, and Gender in Tang China: An Exploration of Bai Juyi's Selected Panwen on Women," Tsinghua China Law Review 1, no. 1 (Spring 2009). The legal aspects of handwritten contracts are discussed in Wu Bingkun 吳秉坤, “Qing zhi Minguo Huizhou tianzhai diandangqi shenxi:jian yu Zheng Limin xiansheng shangque 清至民國 徽州天宅典當契深析: 兼與鄭力民先生商催 [Research into Huizhou Mortgage Contracts from the Qing to the Republic: In Consultation with Mr. Zheng Limin]," Zhongguo jingjishi yanjiu 中國經濟史研究 [Research on Chinese Economic History], no. 1 (2009). Justice as delivered in the world of gods and spirits followed most of the conventions of the secular legal system. For these comparisons, see Paul R. Katz, "Divine Justice in Late Imperial China: A Preliminary Study of Indictment Rituals," in Religion and Chinese Society, Vol. II: Taoism and Local Religion in Modern China, ed. John Lagerwey (Hong Kong: Chinese University Press, 2004), 2. 


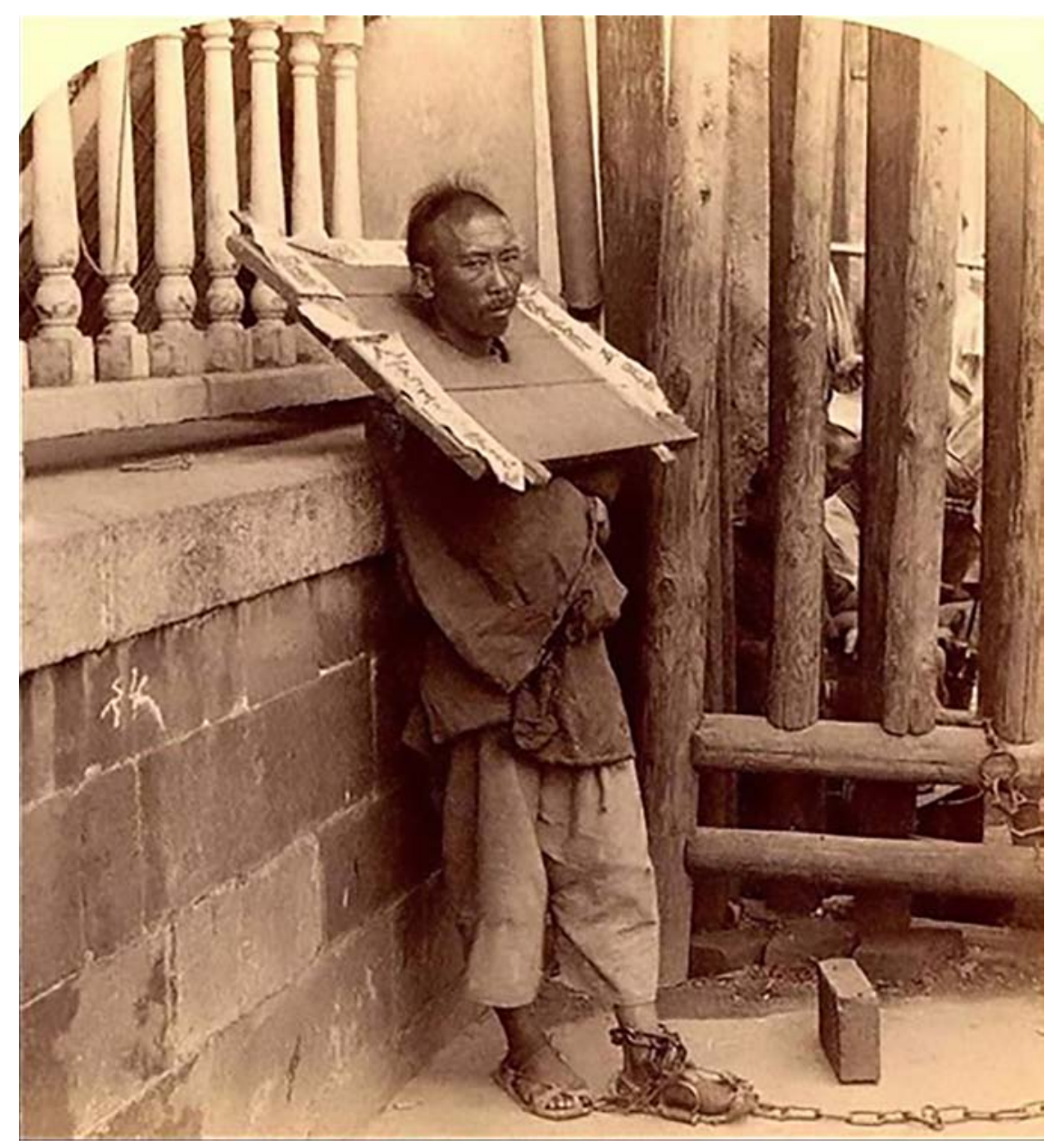

FIGURE 1.17

Cangue. Called mujia 木枷 or jiasuo 枷鎖, in the West they are also called shackles or fetters. The prisoner's name and crime were written on paper and pasted onto the board. This prisoner was supposedly photographed in Hankou 漢 $\square$. Officially it was a device to restrain a prisoner, but it was heavy and inflicted pain, it restricted a person's movements in many ways, and it was a great humiliation to wear. This punishment could be imposed for relatively minor crimes like petty theft or causing a disturbance, and it was removed at night.

PHOTO FROM JAMES RICALTON, THE BOXER UPRISING, CHEEFOO TAKU, TIEN-TSIN: A PART OF UNDERWOOD \& UNDERWOOD'S STEREOSCOPIC TOUR THROUGH CHINA (NEW YORK: UNDERWOOD \& UNDERWOOD, 19O2) 
Four of the cases are discussed here. Each reveals a pivotal aspect of the social values strongly held in traditional China. In case no. 1 (pp. 1-4), "A Rich Man Took Another's Wife by Force" [gao qianghun 告強婚], taking advantage of his position of power and status over the women. This situation is common in all societies where great disparities of wealth exist, which was generally the case in premodern China. In the bare outline of this case given in the manuscript, none of the possible complicating factors are considered, such as any suspicion that the man and the woman had a consensual relationship in any way.

In case no. 2 (pp. 5-7), a “Widow Was Forced to Remarry” [shiduo faqi 势奪髮 妻], in which the late husband's family forced the remarriage, which resulted in the woman's suicide. The accepted morality in traditional China was that a wife, once married, should never remarry, even if it meant living most of her adult life alone. But in a society in which families needed a mate for a son and an additional person to labor on behalf of the family, this rule was not necessarily honored. Forcing a woman to contradict the accepted morality, in this case causing her to commit suicide, is a good example of the conflict between ideal prescribed behaviors and the more difficult exigencies of everyday reality, such as the expectation by the groom's family that, in a few years, they would have another person to labor in their household.

In case no. 3 (pp. 7-9), a "Marriage Contract Was Repudiated" [gao letuiqin 告勒退親]. It was not uncommon for families to arrange a marriage contract while both the prospective groom and prospective bride were still children, with the proviso that the contract would come into force in the future, usually when the children reached puberty. In this case, when the time for marriage arrived, one family decided it did not want to follow through with the marriage, and the second family believed it had been cheated. Sometimes, the future bride was sent to live with the family of her future husband. While living with them, she would provide labor for the family, and the family probably believed it had already "captured" the prospective bride. In the case outlined in this manuscript, the groom's family failed to acquire the bride, who was not physically living with it.

Case no. 4 (pp. 9-11) is about the "Forcible Rape of a Young Girl" [qiangjian guinü 強茹閏女]. The girl in question was a servant in the house of someone well-to-do. The circumstances of this case are discussed at length, pointing out the difference in economic status between the rapist and the poor servant girl and the failure of the rapist's family to protect the girl. The story became the basis of operas and literary fiction because it threw into sharp relief the inequities and power differences permeating Chinese society. Servants were/are regularly taken advantage of sexually in all societies, so this case has near-universal relevance. 
In each of these cases, the chief protagonist is a young female. We can conclude from this that young women were especially vulnerable in China's patriarchic social system, especially when they had no financial wealth to give them any social position. It is likely that the litigator had to deal with grievances of this sort on a regular basis because he was dealing with pingmin who had been taken advantage of, and so he copied these cases to his manuscript. We should also be open to the possibility that these cases all held a degree of sexual titillation for the male litigator, because they involved young females. ${ }^{44}$

The remainder of this book (pp. 17-44) contains entirely different subject matter. It describes a method of telling fortunes by casting dominoes [yapai bazhong 牙牌八種]. The meanings of all the possible ways in which the dominoes might be aligned [shengua 神卦] are explained. ${ }^{45}$ The inclusion of this material is a strong indication that the litigator, being literate and considered to have wider experience in human affairs than the average person, was also a professional fortuneteller who used the material he had copied into this book for both aspects of his work. At the same time, casting the dominos might have been his favorite pastime. Either way, once again this manuscript, with its two divergent sets of content, demonstrates that these minjian chaoben should be seen as notebooks consulted by people who compiled them for their own use.

44 The kinds of cases commonly presented for litigation involving women included: marriage contract disputes, forced remarriage, abandonment, abuse, seduction, rape, and suicide. See Philip C.C. Huang, Code, Custom, and Legal Practice in China: The Qing and the Republic Compared (Redwood City, CA: Stanford University Press, 2001), especially chap. 9. The Red Shore, discussed here, contains only a portion of text taken from another source and was used for reference by an informal litigator. But complete manuals, often several volumes long, were published for the use of the litigators. One of these is discussed extensively in Fuma Susumu 夫馬進, “Shōshi mihon [XiaoCao yibi] no shutsugen 訟師祕本 [蕭曹遺 筆] の出現 [A Litigator's Handbook: The Received Writings of Mr. Xiao and Mr. Cao]," Shirin 史林 [Historical Studies], 77, no. 2 (March 1994). Cases of homicide and potential rebellion against the government are translated and discussed in Robert E. Hegel, True Crimes in Eighteenth-Century China: Twenty Case Histories (Seattle: University of Washington Press, 2009). My understanding of this text was greatly expanded by my discussion with He Zhaohui 何朝暉 at Shandong University.

45 The casting of dominos is covered in Yapai shenshu bazhong 牙牌神數八種 [Eight Methods for Divine Readings by Casting Dominos] (Taipei: Wenhua tushu gongsi, 1961). 


\section{Conclusion}

This chapter provides the context for chaoben, that are focus of this study. These handwritten materials reflect the lives and concerns of the common people of China over a century. Many of those people were illiterate, but they managed to use these manuscripts to learn some characters or they listened as the texts were read aloud or chanted at a religious service. These chaoben intersected with many areas of their daily lives. This chapter presents a sampling of the different types of chaoben used by the common people.

By 1950, printed materials were found everywhere in China. Yet the common people, whether they lived in large cities, small cities with their bustling markets, or the countryside, continued to copy materials by hand and to bind the materials together in the form of books. These items are characteristic of the popular manuscript culture [minjian chaoben wenhua 民間抄本文化].

Although they looked like traditional string-bound books, chaoben should be considered notebooks in which the people reproduced texts and information that they found useful and interesting. Many of them contain several sections on seemingly unrelated topics. But the topics in each individual volume were in fact related by the interests and needs of the person who selected them for copying, whether on their own or by someone else. For example, I have a book titled Funeral Orations (Jiwen 祭文). ${ }^{46}$ The man who wrote a number of funeral oration texts in the book as part of his familial obligations of conducting a ceremony at the grave of an ancestor, on the later pages also copied portions of a rhyming dictionary most likely because he enjoyed composing poetry or because he was a teacher of poetry. The man who gave legal advice as a litigator in The Red Shore also enjoyed telling fortunes through casting dominos, so the manuscript he prepared contains both types of information.

46 The cover page has fallen away from this book, so it has no title, but I refer to it as Funeral Orations [Jiwen 祭文], or eulogies. It likely dates from the early Republican era, because the text contains the phrase Great Han Republic [Dahan minguo 大漢民 國], which later became the standard Zhonghua minguo 中華民國. It is $7^{1 / 2} \mathrm{in}(18.41 \mathrm{~cm})$ $\mathrm{h} \times 4^{1 / 4}$ in $(10.79 \mathrm{~cm})$ w; I bought it in Guilin in September 2005. It seems to refer to Central or South China, which would be logical, based on my assumption that in general these materials appear in markets in the geographic region, widely defined, where they originated. The funeral orations are on pp. $5^{-19}$, followed by the poetic rhymes section on pp. 21-54, based on the Kangxi zidian 康熙字典 [Kangxi Dictionary], a work that has been popular for several hundred years and has been widely reprinted, and continues to be on sale today in China. 
Virtually every manuscript in this genre had an economic function. It was used as part of an exchange of information or advice to help its owner earn a living. That was probably the reason for compiling the book in the first place. We assume that most of the men who copied these materials and who used the books in the performance of their professions were xiucai. They had managed to acquire a solid basic education, which they used to earn income in a society in which most people were not functionally literate. Xiucai used their skills at reading and writing and as possessors of "knowledge," acquired through their formal education, to engage in a number of professions. The professions, as revealed through the chaoben discussed in this chapter, included those as fortuneteller, litigator, ritual specialist, elementary school teacher, medical advisor, professional writer who prepared wedding or birth announcements, writer of congratulatory scrolls, and scribe. Chaoben that reflect all these categories are for sale at China's flea and antiques markets today. We should assume that some of these chaoben were compiled for the personal pleasure and private use of the person who produced them, in spite of the assumption that most were made for monetary reasons and were part of an economic transaction.

Xiucai worked at the intersection of the literate and the illiterate or semiliterate common people. The common people consulted these professionals in the course of daily life, so the record of information, ideas, and values presented in the chaoben prepared by the xiucai reflect common people's needs, aspirations, and values.

Because the authors and copyists of these books saw them as notebooks to be used in daily life, they were uninhibited about what kind of information they added to them. Happily for us, their jottings allow us to broaden our understanding of the men who wrote and used chaoben and, by implication, the less literate common people who consulted with them. The chaoben in my collection (only a few representative examples are discussed in this chapter) show, for example, that a good recipe for Chinese medicine was always appreciated and so was often copied into its pages (examples of this are illustrated in other chapters, including a full medicinal recipe in Chapter 4). We can imagine the frustration of the xiucai who noted that he had to study yinyang practices in order to earn a living or the pride of the merchant who worked hard at his family's business and expressed himself in a poem in Various Words Offered to the People; his original poem was by no means highly accomplished, but it revealed his determination to work for the sake of his extended family.

Chaoben are cultural artifacts created by the common people of China. They lay out before us the rich perceptual life of ordinary Chinese as they went about fulfilling their daily obligations, planning for transitional life events, and struggling to understand difficult issues. Each chaoben indicates the ways in which 
the received teachings and values of the traditional culture were reinterpreted at the local level in ways understandable to the common people. They took the generalized or universalized values and practices from the received tradition and explained them in concrete ways. In doing so, as Kleinman taught us, they created a culture specific to their time and place that was relevant to their daily lives. Chaoben thus reveal the lives of China's common people during the vibrant century of change between $185^{\circ}$ and $195^{\circ}$. 